УДК $551.464 .3(1-924.71)$

\title{
ПЕРВЫЕ РЕЗУЛЬТАТЫ КОМПЛЕКСНЫХ ИЗОТОПНО-ГИДРОГЕОХИМИЧЕСКИХ ИССЛЕДОВАНИЙ НОВОБИБЕЕВСКОГО ПРОЯВЛЕНИЯ РАДОНОВЫХ ВОД
}

\author{
Новиков Дмитрий Анатольевич1,2, \\ NovikovDA@ipgg.sbras.ru
}

\section{Дульцев Федор Федорович1, DultsevFF@ipgg.sbras.ru}

\author{
Максимова Анастасия Алексеевна ${ }^{1,2}$, \\ rock.nastaya64@gmail.com
}

\section{Пыряев Александр Николаевич3,2, pyrayev@igm.nsc.ru}

\author{
Фаге Алексей Николаевич1, \\ FaguetAN@ipgg.sbras.ru
}

\author{
Хващевская Альбина Анатольевна 4 , \\ unpc_voda@mail.ru
}

\author{
Деркачев Антон Сергеевич², \\ a.derkachev@g.nsu.ru
}

\section{Черных Анатолий Витальевич 1 ChernykhAV@ipgg.sbras.ru}

\footnotetext{
1 Институт нефртегазовой геологии и геофизики им. А.А. Трофимуука СО РАН, Россия, 630090, г. Новосибирск, пр. Академика Коптюга, 3.

2 Новосибирский национальный исследовательский государственный университет, Россия, 630090, г. Новосибирск, ул. Пирогова, 1.

3 Институт геологии и минералогии им. В.С. Соболева СО РАН, Россия, 630090, г. Новосибирск, пр. Академика Коптюга, 3.

4 Национальный исследовательский Томский политехнический университет, Россия, 634050, г. Томск, пр. Ленина, 30.
}

\begin{abstract}
Актуальность исследования заключается в получении первых изотопно-геохимических данных о природных водах и вмещающих горных породах Новобибеевского проявления радоновых вод.

Цель: изучить особенности химического состава природных вод и водовмещающих пород и получить первые сведения по активности ${ }^{222} \mathrm{Rn}$ и изотопному составу $\delta D, \delta^{18} \mathrm{O}, \delta^{13} \mathrm{C}$.

Методы. Лабораторное изучение химического состава методами титриметрии, ионной хроматографии, масс-спектрометрии с индуктивно связанной плазмой проводилось в ПНИЛ гидрогеохимии ИШПР ТПУ. Определение комплекса величин $\delta D, \delta^{18} \mathrm{O}, \delta^{13} C_{D I C}$ вод и растворенного неорганического углерода (Dissolved Inorganic Carbon (DIC)) проводилось в центре коллективного пользования ИГМ СО РАН с помощью прибора Isotope Ratio Mass Spectrometer Finnigan ${ }^{T M}$ MAT 253, снабженного приставками пробоподготовки H/Device (для определений $\delta D$ ) u GasBench II (для определений $\delta^{18} \mathrm{O}$ и $\delta^{13} \mathrm{C}_{\mathrm{DIC}}$ ). Измерение содержаний $222 R n$ в водах проводилось на комплексе «Альфрарад плюс» в лаборатории гидрогеологии осадочных бассейнов Сибири ИНГГ СО РАН. Геофризические исследования проводились с применением электроразведочной аппаратуры Скала-48 с 48 электродами и шагом между ними 5 м, по электроразведочной схеме Шлюмберже. Разделение данных на однородные геохимические совокупности выполнено с помощью коэфффициентов $\mathrm{Ca} / \mathrm{Na}, \mathrm{Ca} / \mathrm{Mg}, \mathrm{Ca} / \mathrm{Si}, \mathrm{Mg} / \mathrm{Si}, \mathrm{Na} / \mathrm{Si}$. Для выявления степени концентрирования химических элементов в природных водах были рассчитаны коэфрфициенты концентрации $K k_{i}=\frac{m_{x}}{n_{x}}$ и водной миграции (по А.И. Перельману) $K x_{1}=\frac{m_{x} \cdot 100}{a \cdot n_{x}}$.
\end{abstract} Результаты. Выполнены комплексные изотопно-геохимические исследования радоновых вод Новобибеевского проявления. Радоно-

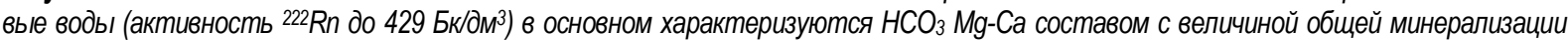

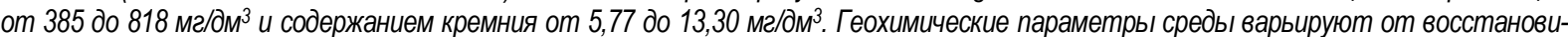

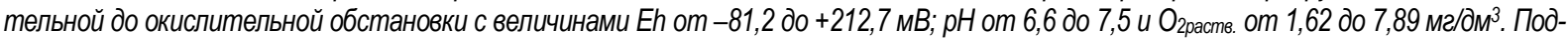
земные воды были разделены на две геохимические совокупности: 1) трещинно-жильные воды гранитоидов с отношениями Ca/Si 11,49; Mg/Si 2,48; $\mathrm{Na} / \mathrm{Si}$ 1,25; Si/Na 0,87; Ca/Na 10,02; Ca/Mg 4,76; $\mathrm{rNa} / \mathrm{rCl} 8,79$ и SO4/Cl 4,35 и 2) воды зоны региональной трещиноватости гранитоидов в условиях антропогенного влияния с отношениями $\mathrm{Ca} / \mathrm{Si} \mathrm{16,43;} \mathrm{Mg/Si} \mathrm{2,21;} \mathrm{Na} / \mathrm{Si}$ 2,21; Si/Na 0,62; Ca/Na 9,84; Ca/Mg 9,95; $\mathrm{rNa} / \mathrm{rCl}$ 0,89 и SO4/Cl 1,78. Поверхностные воды в условиях техногенной нарушенности по составу $\mathrm{SO}_{4}-\mathrm{HCO}_{3} \mathrm{Na-Mg-Ca} \mathrm{c} \mathrm{величи-}$

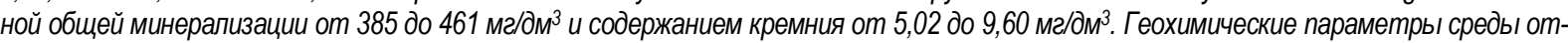

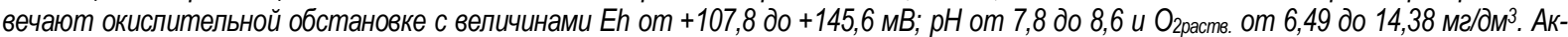
тивность радона в водах не превышает 39 Бк/2м³. Поверхностные воды реки Ояш характеризуются в основном $\mathrm{HCO}_{3} \mathrm{Na}-\mathrm{Mg}$-Сa co-

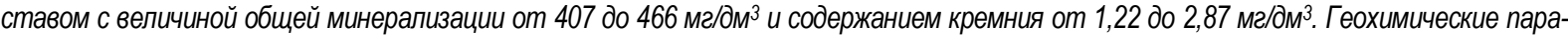
метры среды отвечают окислительной обстановке с величинами Eh om +120,1 до +150,0 мB; pH om 8,4 до 8,5 u O2раств. от 7,45 до 9,53 мә/дм³. Активность радона в речных водах варьирует от 1 до 12 Бк/дм³. С ростом общей минерализации в радоновых водах концентрируются $\mathrm{Li}, \mathrm{Cr}, \mathrm{Zn}, \mathrm{Br}$, Sr u U. На спектре их распределения наиболее высокие содержания (ме/дм³) закономерно установлены у: Si do 8,85, Mn dо 0,22, Fe до 0,34, Sr до 0,77 и Ba до 0,13, поскольку водовмещающие породы представлены биотитовыми гранитами, порфрировидными и оливиновыми долеритами. B водах в большей мере накапливаются $\mathrm{Br}, \mathrm{I}, \mathrm{Se}, \mathrm{Te}, \operatorname{Re}$ и U, а наибольшей миграционной способностью в этих условиях отличаются I, Se, Br, Te, Re, U, B, Sr u Mo. Изотопный состав (סD от -139,4 до -112,5\%о и $\delta^{18} \mathrm{O}$ от $-18,9$ до -14,4\%) и расположение точек на диаграмме $\delta D=f\left(\delta^{18} 0\right)$ указывает на метеорное происхождение всех изученных вод. Полученные значения $\delta^{13} C_{\text {DIc }}$ варьируют в диапазоне от $-14,2$ до -10,0\% при содержании DIC om 3,4 до 8,7 ммоль/Дм³. Основным источником водорастворенной углекислотыявляется почвенная углекислота смешанного состава.

\section{Ключевые слова:}

Радоновые воды, стабильные изотопы, радон, генезис вод, граниты, новое проявление радоновых вод «Новобибеевское», Новосибирская область, Западная Сибирь. 


\section{Введение}

В настоящее время в научных и производственных кругах наблюдается устойчивый интерес к изучению минеральных вод различного изотопногеохимического облика и бальнеологической ценности. Эта общемировая тенденция связана с быстро растущим рынком бутилированных вод и спросом населения на бальнеолечение (бурное развитие SPAиндустрии). Радоновые воды не являются исключением. Научная проблема о природе радиоактивности подземных вод стоит среди наиболее актуальных в гидрогеохимии, начиная с работ В.И. Вернадского [1] Наибольшее число опубликованных в мире работ посвящено изучению геологических, гидрогеологических и геохимических факторов, влияющих на распределение природных радионуклидов в водах [2-9 и другие]. Ряд исследований посвящено радиоактивному загрязнению вод и грунтов месторождений полезных ископаемых [10-12]. В некоторых публикациях рассматривается пагубное воздействие ${ }^{227} \mathrm{Ac},{ }^{40} \mathrm{~K}$ ${ }^{210} \mathrm{~Pb},{ }^{210} \mathrm{Po},{ }^{226} \mathrm{Ra},{ }^{228} \mathrm{Ra},{ }^{228} \mathrm{Th},{ }^{230} \mathrm{Th},{ }^{232} \mathrm{Th},{ }^{234} \mathrm{U},{ }^{238} \mathrm{U}$ и тяжелых металлов на окружающую биоту $[13,14]$. Например, в исследованиях $[15,16]$ приводятся факты по основной роли горнодобывающей промышленности в загрязнении почв As, W, Hg, Sr, Th и U. Cpeди последних комплексных работ по изучению распределения радионуклидов в водах питьевого назначения и их влиянию на здоровье человека можно привести $[17,18]$.

Радоновые воды пользуются широким распространением в Новосибирской области (НСО). Как правило, они связаны с крупными гранитоидными массивами Новосибирским, Приобским, Барлакским и другими. Большинство из проявлений и месторождений радоновых вод было открыто в 1970-80-х гг., но при этом они отличаются крайне низкой степенью гидрогеологической изученности [19-22]. Последние сведения по радоновым водам Новосибирской области приводятся в работах [23-29]. В полевой сезон 2019 г., связанный с изучением качества подземных вод нецентрализованного водоснабжения населения $\mathrm{HCO}$, была опробована серия скважин в селе Новобибеево, расположенном в западной части Болотнинского района (рис. $1, a$ ). В результате лабораторных исследований в ряде проб была установлена высокая активность ${ }^{222} \mathrm{Rn}\left(\right.$ до 429 Бк/дм $\left.{ }^{3}\right)$. Скважины повторно опробовались в 2020-2021 гг., что позволило подтвердить полученные ранее результаты. Проявление установлено в пределах Приобского монцодиоритграносиенит-гранитового мезоабиссального комплекса.

Схожей активностью радона до 500 Бк/дм³ обладают природные воды португальских регионов Трасос-Монтес и Альто-Дору [30]; горячих источников районов Тата Пани, Гилгит (Пакистан) [31]; медного пояса Кхетри в Раджастане (Индия) [32]; Польши [33]; Румынии [34] и других регионов мира. Поэтому целью настоящей работы является получение актуальных данных по изотопно-геохимическим особен- ностям радоновых вод и водовмещающих пород Новобибеевского проявления.

\section{Материалы и методы}

За три года исследований (2019-2021) была отобрана 21 проба подземных вод из скважин, которые расположены непосредственно в селе, 5 проб - в пределах разрабатываемого карьера бутового камня «Новобибеевский» и 3 пробы - из реки Ояш (рис. 1, б). Лабораторное изучение химического состава методами титриметрии, ионной хроматографии, массспектрометрии с индуктивно связанной плазмой проводилось в ПНИЛ гидрогеохимии ИШПР ТПУ. Название химического типа дано по классификации С.А. Щукарева (в формулу добавлены макрокомпоненты с содержанием >10 \%-экв) по оттеночному принципу от меньшего к большему.

Определение комплекса величин $\delta \mathrm{D}, \delta^{18} \mathrm{O}, \delta^{13} \mathrm{C}_{\mathrm{DIC}}$ вод и растворенного неорганического углерода (Dissolved Inorganic Carbon (DIC)) проводилось в центре коллективного пользования ИГМ СО РАН с помощью прибора Isotope Ratio Mass Spectrometer Finnigan $^{\mathrm{TM}}$ MAT 253, снабженного приставками пробоподготовки H/Device (для определений $\delta \mathrm{D}$ ) и GasBench II (для определений $\delta^{18} \mathrm{O}$ и $\delta^{13} \mathrm{C}_{\mathrm{DIC}}$ ). Значения $\delta^{13} \mathrm{C}_{\mathrm{DIC}}, \delta \mathrm{D}$ и $\delta^{18} \mathrm{O}$ измерялись по известным методикам [35-38] относительно мировых стандартов: VSMOW2; SLAP2; GISP - для анализа водорода и кислорода; NBS-18; NBS-19 - для анализа углерода. Ошибка определения изотопного состава стандартов по углероду и кислороду - не более 0,1 \%, по водороду - не более 2 \%. Для удаления песка, мелкодисперсных взвесей и возможных примесей на месте отбора пробы фильтровались через нейлоновый фильтр (Nylon-0,45/25), собирались в герметичные пробирки 50 мл, пробки обматывались парафильмом (parafilm) для минимизации газообмена с окружением при транспортировке и хранении. Измерение содержаний ${ }^{222} \mathrm{Rn}$ в водах проводилось на комплексе «Альфарад плюс» в лаборатории гидрогеологии осадочных бассейнов Сибири ИНГГ СО РАН.

В комплекс полевых исследований 2020 г. также входили геофизические работы методом электротомографии. Исследования производились с применением электроразведочной аппаратуры Скала-48 с 48 электродами и шагом между ними 5 м по электроразведочной схеме Шлюмберже.

Разделение данных на однородные геохимические совокупности по процессам формирования состава с оценкой интенсивности их проявления выполнено на основе соотношения химических элементов в водах. Коэффициенты $\mathrm{Ca} / \mathrm{Na}, \mathrm{Ca} / \mathrm{Mg}, \mathrm{Ca} / \mathrm{Si}, \mathrm{Mg} / \mathrm{Si}, \mathrm{Na} / \mathrm{Si}$ использованы для оценки особенностей обогащения вод за счет процессов гидролиза алюмосиликатов и конгруэнтного растворения карбонатов; $\mathrm{SO}_{4} / \mathrm{Cl}>>1$ и $\mathrm{rNa} / \mathrm{rCl} \gg 1$ - гидролиза алюмосиликатов и окисления сульфидных минералов; пропорциональное увеличение значений $\mathrm{SO}_{4} / \mathrm{Cl}=1, \mathrm{rNa} / \mathrm{rCl} \geq 1, \mathrm{Ca} / \mathrm{Na}>0$ - испарительного концентрирования. 


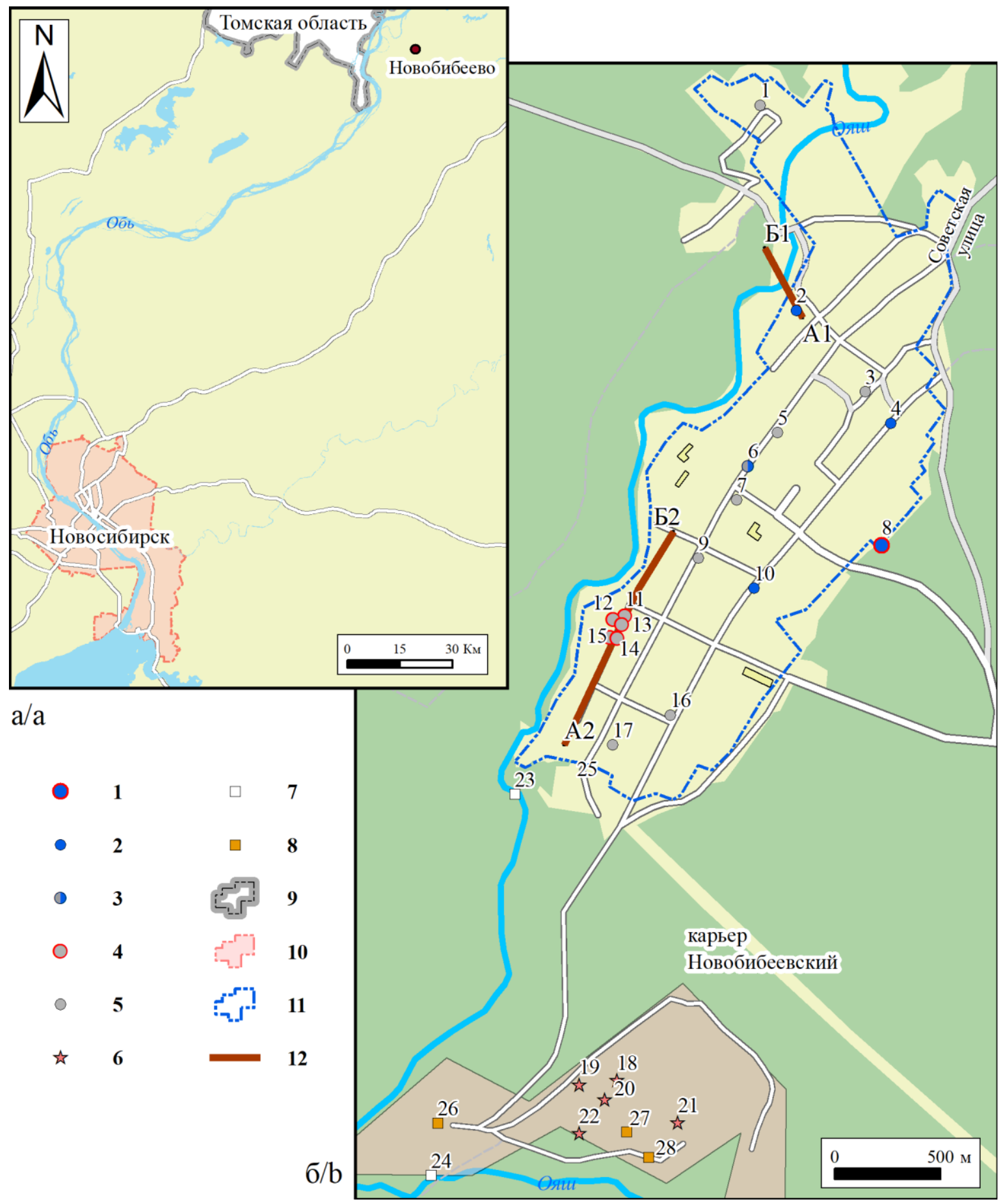

Рис. 1. Местоположение Новобибеевского проявления радоновых вод (а) и изученных объектов в его пределах (б). Воды: 1-5 - подземные: 1 - трещинно-жильные воды гранитоидов (группа I), с аномальной активностью радона; 2 - трещинно-энильные воды гранитоидов (группа I); 3 - I и II типов; 4 - воды зоны региональной трещиноватости гранитоидов в условиях антропогенного влияния (группа II) с аномальной активностью радона; 5 - воды зоны региональной трещиноватости гранитоидов в условиях антропогенного влияния (группа II); 6 - поверхностные воды в условиях техногенной нарушенности (группа III); 7 - поверхностные воды реки Ояш (группа IV); 8 - место отбора образиов горных пород; границы: 9 - Новосибирской области; 10 - г. Новосибирска; 11 - с. Новобибеево; 12 - линия геофизического профиля

Fig. 1. Location of the Novobibeevo occurrence of radon-rich waters (a) and the studied objects within its boundaries $(b)$. Waters: 1-5 - groundwaters: 1 - fracture-vein waters in granitoids (group I), with anomalous radon activity; 2 - fracture-vein waters in granitoids (group I); 3 - I and II types; 4 - waters of the zone of regional fracturing of gra-nitoids under anthropogenic impact (group II) with anomalous radon activity; 5 - waters of the zone of regional fracturing of granitoids under anthropogenic impact (group II); 6 - surface waters under the conditions of technogenic disturbance (group III); 7 - surface waters of the Oyash river (group IV); 8 - rock sampling site; boundaries of: 9 - the Novosibirsk region; 10 - Novosibirsk city; 11 - Novobibeevo settlement; 12 - the geophysical profile line 
Для выявления степени концентрирования химических элементов в природных водах были рассчитаны коэффициенты концентрации $\left(\mathrm{Kk}_{\mathrm{i}}\right)$ и водной миграции по А.И. Перельману $\left(\mathrm{Kx}_{1}\right)$. Первый рассчитывается как: $\mathrm{Kk}_{\mathrm{i}}=\frac{\mathrm{m}_{\mathrm{x}}}{\mathrm{n}_{\mathrm{x}}}$, где $\mathrm{m}_{\mathrm{x}}-$ содержание элемента в воде; $\mathrm{n}_{\mathrm{x}}$ - кларк литосферы в \% (по Н.А. Григорьеву [39]). Второй: $\mathrm{Kx}_{1}=\frac{\mathrm{m}_{\mathrm{x}} \cdot 100}{\mathrm{a} \cdot \mathrm{n}_{\mathrm{x}}}$, где $\mathrm{m}_{\mathrm{x}}-$ содержание элемента в воде $\left(\right.$ мг/дм $\left.{ }^{3}\right) ;$ a - минерализация $\left(\right.$ мг/дм $\left.{ }^{3}\right)$ и $\mathrm{n}_{\mathrm{x}}$ - кларк литосферы в \%.

\section{Результаты и обсуждение}

Гидрогеологическое строение

Село Новобибеево находится на территории Болотнинского района Новосибирской области на правом берегу р. Обь. Непосредственно по территории Новобибеево протекает р. Ояш, впадающая в р. Обь в 3,5 км северо-западнее села. В геоморфологическом отношении исследуемая территория представлена структурами, приуроченными к хорошо проработанным долинам р. Ояш, имеющим плоский тальвег, покрытый пойменным аллювием. Глубина вреза долины по отношению к водоразделам составляет 50-100 м.

Геологический разрез села Новобибеево представлен верхнепалеозойскими гранитоидами, породами нижнего карбона и верхнего девона, палеогеновой, неогеновой и четвертичной систем и отложениями коры выветривания [40].

В гидрогеологическом разрезе установлены безнапорные воды палеозойского фундамента, представленного гранитоидами Обского массива, в состав которых входят серые и розовато-серые порфировидные граниты верхнепалеозойского возраста среднемелкозернистые, реже гранодиориты и прорывающие их дайки долеритов. Интрузивные породы разбиты сетью трещин, образующих единую обводненную зону трещинно-жильных вод, водообильность которой крайне мала. Водообильность скважин варьирует от 0,15 до 0,26 л/с при понижении уровня от 18 до $33 \mathrm{~m}$.
При проведении откачек максимальное понижение уровня в скважинах достигалось практически сразу, на его полное восстановление уходило около двух суток. Вскрытая мощность обводненных гранитоидов достигает 120 м. Они перекрываются водоносным комплексом рыхлых осадочных отложений четвертичного возраста мощностью до 15 м, представленных аллювиальными отложениями р. Ояш, включая русловые, пойменные, первой и второй надпойменных террас и субэральные нижне-средненеоплейстоценовые отложения краснодубровской свиты. Кора выветривания гранитоидов на исследуемой территории сохранилась лишь в виде отдельных, небольших по площади участков, что объясняет гидравлическую взаимосвязь между водоносными горизонтами по всей площади их распространения. Абсолютные отметки зеркала подземных вод уменьшаются от 196,3 до 187,4 м в направлении русла р. Ояш, урез которой находится на уровне 186,9 м.

Особенности гидрогеологического строения изучаемой территории хорошо видны на геоэлектрических разрезах по профилям А1-Б1 и А2-Б2 (рис. 1, б, рис. 2). Согласно первому разрезу, мощность рыхлых отложений увеличивается в направлении русла р. Ояш от менее чем 5 м в интервале 0-70 м по профилю исследования до 5-7 м в интервале 70-120 м. Ниже, согласно данным инверсии, залегают высокоомные (1000-2000 Ом'м) толщи - верхнепалеозойские гранитоиды. Мощность этой зоны составляет 10-15 м. Высокие значения УЭС, вероятнее всего, говорят о весьма низкой трещиноватости и обводненности пород. Интервал глубин 15-70 м характеризуется относительно низкими значениями УЭС (20-100 Ом`м). Объяснение этому может быть только одно - наличие обводненной зоны трещиноватости в гранитоидах. Таким образом, можно судить о глубине залегания и мощности зоны трещиноватости: кровля залегает на глубине 15 м, подошва - глубже 45 м.

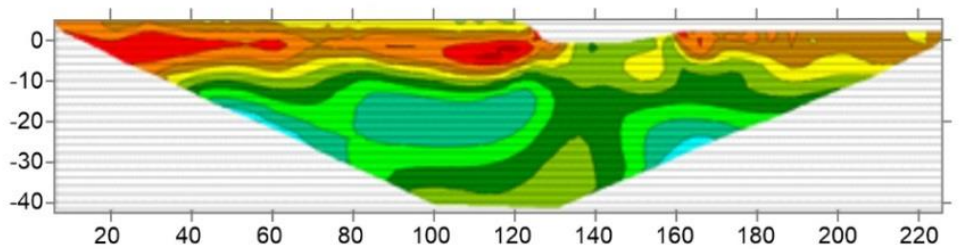

A2

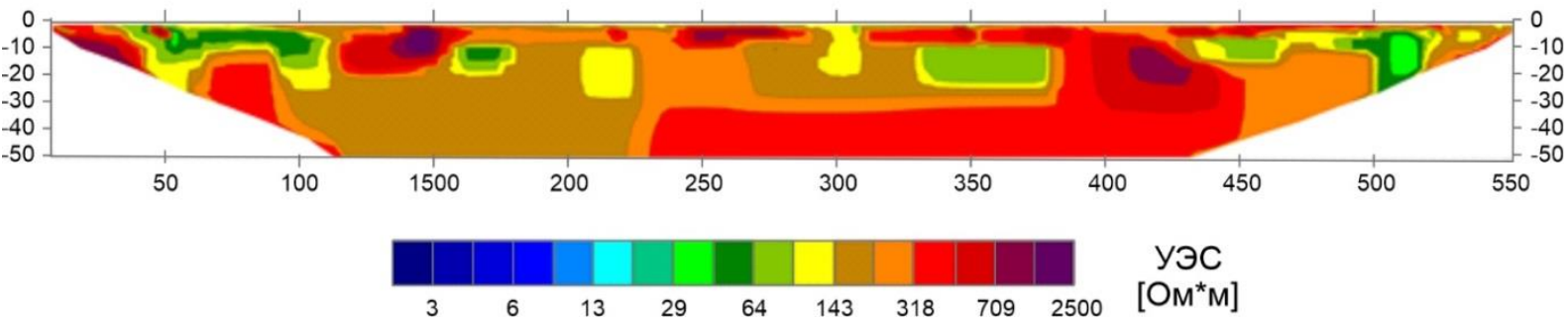

Рис. 2. Геоэлектрические разрезы по профилям А1-Б1, А2-Б2, схема исследования Шлюмберже

Fig. 2. Geoelectric sections along A1-Б1, A2-Б2 profiles, investigation scheme: Schlumberger 
Второй геоэлектрический разрез существенно отличается от рассмотренного выше - он в целом значительно более высокоомный, с отдельными относительно проводящими зонами. Участки повышенной трещиноватости в верхней и средней частях разреза характеризуются значениями УЭС от 40 до 100 Ом·м. Нижняя часть является высокоомной (значения УЭС от $\left.300 \mathrm{OM}^{*} \mathrm{M}\right)$, что говорит о прочности пород и отсутствии в них свободной воды на глубинах более 30 м. Кроме того, в верхней части разреза хорошо прослеживаются водообильные зоны интервалах 40-110 и 500-520 м по профилю.

\section{Геохимия природных вод}

Анализ имеющихся данных по составу природных вод позволил выделить четыре геохимические совокупности (группы вод): трещинно-жильные воды гранитоидов (группа I), воды зоны региональной трещиноватости гранитоидов в условиях антропогенного влияния (группа II), поверхностные воды в условиях техногенной нарушенности (группа III) и поверхностные воды реки Ояш (группа IV). Первые две геохимические группы природных вод, связанных с гранитными массивами, впервые выделены нами ранее [26].

Первые (I) изучены в водозаборной (централизованного водоснабжения поселка) скважине и в скважинах на улицах Молодежная, Советская, Школьная и (табл. 1). Они характеризуются $\mathrm{HCO}_{3} \mathrm{Mg}-\mathrm{Ca}$ составом (рис. 3) с величиной общей минерализации от 483 до 594 мг/дм ${ }^{3}$. Содержания кремния не превышают 13,30 мг/дм ${ }^{3}$. Геохимические параметры среды варьируют от восстановительной до окислительной обстановки с величинами Eh от $-81,2$ до $+56,0 \mathrm{mB}$; $\mathrm{pH}$ от 7,3 до 7,5 и $\mathrm{O}_{2 \text { раств. }}$ от 1,62 до 7,76 мг/дм ${ }^{3}$. Средние значения геохимических коэффициентов для данной группы составляют: $\mathrm{Ca} / \mathrm{Si} 11,49 ; \mathrm{Mg} / \mathrm{Si}$ 2,48; $\mathrm{Na} / \mathrm{Si}$ 1,25; $\mathrm{Si} / \mathrm{Na} 0,87 ; \mathrm{Ca} / \mathrm{Na} 10,02 ; \mathrm{Ca} / \mathrm{Mg} 4,76 ; \mathrm{rNa} / \mathrm{rCl} 8,79$ и $\mathrm{SO}_{4} / \mathrm{Cl} 4,35$, что свидетельствует о накоплении в водах кальция, магния и протекании процессов окисления сульфидов. Содержания радионуклидов составляют (мг/дм $\left.{ }^{3}\right):{ }^{238} \mathrm{U}$ от $5,25 \cdot 10^{-4}$ до $3,97 \cdot 10^{-2}$ и ${ }^{232} \mathrm{Th}$ от $4,04 \cdot 10^{-7}$ до $2,43 \cdot 10^{-5}$. Отношение ${ }^{232} \mathrm{Th} /{ }^{238} \mathrm{U}$ варьирует в интервале от $2,25 \cdot 10^{-4}$ до $2,92 \cdot 10^{-2}$ при среднем $6,79 \cdot 10^{-3}$. Активность радона в водах изменяется в широких пределах от 6,5 до 97,0 Бк/дм³ ${ }^{3}$. Невысокие концентрации ${ }^{222} \mathrm{Rn}$ в водозаборной скважине (№ 2 на рис. 1, б) связаны с высокой трещиноватостью выветрелых гранитов.

Наиболее многочисленная вторая группа (II) (табл. 1) представлена в основном водами $\mathrm{HCO}_{3}$ $\mathrm{Mg}-\mathrm{Ca}$ состава. Величина общей минерализации изменяется в интервале от 385 до 818 мг/дм³ жания кремния - от 5,77 до 9,85 мг/дм ${ }^{3}$. Геохимические условия среды отвечают окислительной обстановке с Еh от 63,4 до 212,7; pH от 6,6 до 7,5 и $\mathrm{O}_{2 \text { раств }}$ от 1,80 до 7,89 мг/дм ${ }^{3}$. По отношению к первой группе возрастают средние значения геохимических коэффициентов: $\mathrm{Ca} / \mathrm{Si} 16,43 ; \mathrm{Na} / \mathrm{Si} 2,21 ; \mathrm{Ca} / \mathrm{Mg} 9,95$, снижаются: $\mathrm{Mg} / \mathrm{Si}$ 2,21; $\mathrm{Si} / \mathrm{Na} 0,62 ; \mathrm{Ca} / \mathrm{Na} 9,84 ; \mathrm{rNa} / \mathrm{rCl}$ 0,89 и $\mathrm{SO}_{4} / \mathrm{Cl} 1,78$. При протекании процессов формирования состава вод второй группы существенную роль играют кальциевые алюмосиликаты. Широко проявлены процессы антропогенного загрязнения подземных вод, что отмечается в росте концентраций $\left(\right.$ мг/дм $\left.{ }^{3}\right): \mathrm{SO}_{4}$ до $157 ; \mathrm{Cl}$ до 66,8; $\mathrm{NO}_{3}$ до 259; $\mathrm{Na}$ до 37,$6 ; \mathrm{Br}$ до 0,13; Sr до 1,49 и других. Содержания радионуклидов составляют (мг/дм $\left.{ }^{3}\right):{ }^{238} \mathrm{U}$ от $1,05 \cdot 10^{-3}$ до $1,25 \cdot 10^{-1}$ и ${ }^{232} \mathrm{Th}$ от $1,86 \cdot 10^{-7}$ до $4,16 \cdot 10^{-5} \cdot{ }^{232} \mathrm{Th} /{ }^{238} \mathrm{U}$ отношение в радоновых водах изменяется в интервале от $2,63 \cdot 10^{-5}$ до $3,20 \cdot 10^{-3}$ при среднем $9,52 \cdot 10^{-4}$. Активность радона в водах варьирует в широких пределах от 4,0 до 429,0 Бк/дм ${ }^{3}$. Наиболее высокая активность ${ }^{222} \mathrm{Rn}$ выявлена в скважинах на ул. Набережная (№ 11-15 на рис. 1, б), которая находится в диапазоне от 163 до 429 Бк/дм³ и зависит от величины инфильтрационного питания атмосферными осадками.

Третья геохимическая разновидность (группа III) при общей схожести химического состава отличается от первых значительным ростом сульфат-иона с долей до 10,1-20,4 \%-экв (табл. 1, рис. 3) и локализована в пределах разрабатываемого карьера «Новобибеевский» (рис. 1, б). Величина их общей минерализации составляет 385-461 мг/дм ${ }^{3}$. Содержание кремния изменяется в интервале от 5,02 до 9,60 мг/дм ${ }^{3}$ (рис. 1, б). Геохимические параметры среды отвечают окислительной обстановке с величинами Eh от $+107,8$ до $+145,6 \mathrm{мB}, \mathrm{pH}$ от 7,8 до 8,6 и $\mathrm{O}_{2 \text { раств. }}$ От 6,49 до 14,38 мг/дм ${ }^{3}$. Процессы накопления в водах магния, кальция и натрия отражаются в величинах средних геохимических коэффициентов, которые составляют: $\mathrm{Ca} / \mathrm{Si}$ 9,55; $\mathrm{Mg} / \mathrm{Si} 3,07 ; \mathrm{Na} / \mathrm{Si}$ 2,97; $\mathrm{Si} / \mathrm{Na} 0,39 ; \mathrm{Ca} / \mathrm{Na}$ 3,51; $\mathrm{Ca} / \mathrm{Mg} 3,33 ; \mathrm{rNa} / \mathrm{rCl} 8,97$ и $\mathrm{SO}_{4} / \mathrm{Cl} 11,49$. Также отмечаются признаки антропогенного загрязнения, связанные с эксплуатацией карьера. Выявлены высокие значения (мг/дм $\left.{ }^{3}\right): \mathrm{NO}_{2}$ до 1,$01 ; \mathrm{NO}_{3}$ до 51,$70 ; \mathrm{Na}$ до 20,$40 ; \mathrm{NH}_{4}$ до 0,82 . Содержания радионуклидов составляют (мг/дм $\left.{ }^{3}\right):{ }^{238} \mathrm{U}$ от $1,02 \cdot 10^{-2}$ до $1,16 \cdot 10^{-2}$ и ${ }^{232}$ Th от $2,60 \cdot 10^{-6}$ до $3,10 \cdot 10^{-5}$. Отношение ${ }^{232} \mathrm{Th} /{ }^{238} \mathrm{U}$ составляет $2,43 \cdot 10^{-4}-2,69 \cdot 10^{-3}$ при среднем $1,83 \cdot 10^{-3}$. Активность радона в водах варьирует в пределах от 2 до 39 Бк/дм ${ }^{3}$ и не превышает нормы ПДК.

Воды реки Ояш (группа IV) (табл. 1) характеризуются в основном $\mathrm{HCO}_{3} \mathrm{Na}-\mathrm{Mg}-\mathrm{Ca}$ составом. Величина общей минерализации изменяется от 407 до 466 мг/дм ${ }^{3}$, а содержания кремния - от 1,22 до 2,87 мг/дм ${ }^{3}$. Геохимические параметры среды отвечают окислительной обстановке с величинами Eh от $+120,1$ до $+150,0 \mathrm{MB}, \mathrm{pH}$ от 8,4 до 8,5 и $\mathrm{O}_{2 \text { раств. }}$ от 7,45 до $9,53 \mathrm{мг} /$ дм $^{3}$. Средние значения геохимических коэффициентов составляют: $\mathrm{Ca} / \mathrm{Si} 41,62 ; \mathrm{Mg} / \mathrm{Si} 8,90 ; \mathrm{Na} / \mathrm{Si}$ 10,49; $\mathrm{Si} / \mathrm{Na} 0,12 ; \mathrm{Ca} / \mathrm{Na} 4,24 ; \mathrm{Ca} / \mathrm{Mg} 17,82 ; \mathrm{rNa} / \mathrm{rCl}$ 8,44 и $\mathrm{SO}_{4} / \mathrm{Cl} 3,20$, что также говорит о протекании процессов накопления в них магния, кальция и натрия. Содержания радионуклидов составляют (мг/дм $\left.{ }^{3}\right):{ }^{238} \mathrm{U}$ от $2,27 \cdot 10^{-3}$ до $2,77 \cdot 10^{-3}$ и ${ }^{232}$ Th от $6,92 \cdot 10^{-7}$ до $1,75 \cdot 10^{-5}$. ${ }^{232} \mathrm{Th} /{ }^{238} \mathrm{U}$ отношение в радоновых водах изменяется в интервале от $2,50 \cdot 10^{-4}$ до $7,7 \cdot 10^{-3}$ при среднем $3,49 \cdot 10^{-3}$. Активность радона в водах варьирует от 1 до 12 Бк/дм³ . Речные воды также подвержены существенному влиянию процессов антропогенного загрязнения, что отражается в первую очередь ростом в растворе концентраций натрия и магния. 


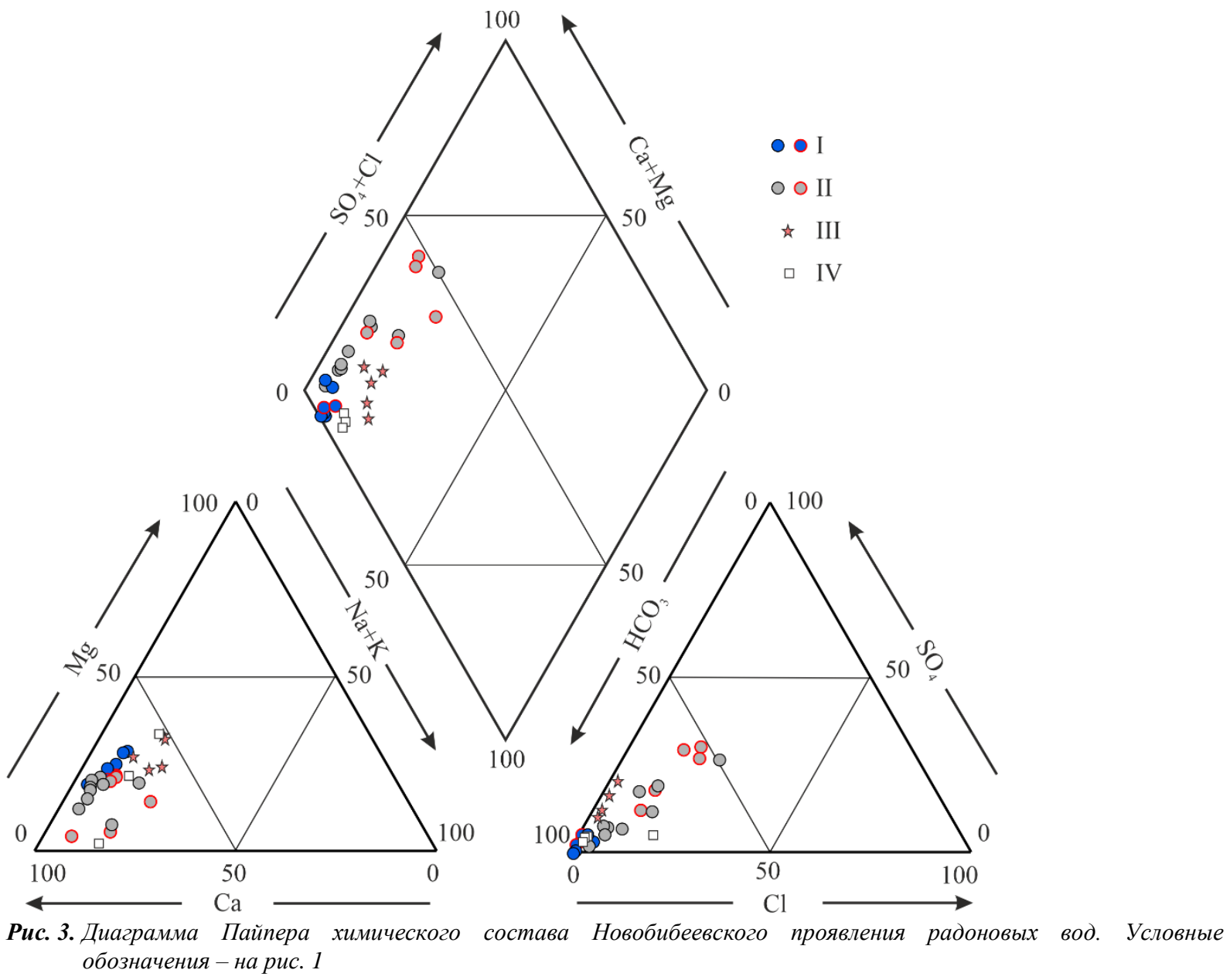

Fig. 3. Piper diagram of the chemical composition of the Novobibeevo radon-rich waters occurrence. For designations, see Fig. 1

Изучение микрокомпонентного состава природных вод села Новобибеево показало, что с ростом общей минерализации в растворе концентрируются $\mathrm{Li}$, $\mathrm{Cr}, \mathrm{Zn}, \mathrm{Br}, \mathrm{Sr}$ и U, а содержания B, V, As, Nb, Mo, Au снижаются. На спектре их распределения (рис. $4, a)$ наибольшие концентрации (мг/дм3) установлены у: $\mathrm{Si}$ до $8,85, \mathrm{Mn}$ до 0,22, Fe до 0,34, $\mathrm{Sr}$ до $0,77, \mathrm{Ba}$ до 0,13 .

Для оценки степени накопления в водах химических элементов были рассчитаны коэффициенты концентрации, которые отражают отношение содержаний элементов в воде к вмещающим породам или к кларку литосферы и коэффициенты водной миграции (по А.И. Перельману) [41]. Согласно рассчитанным коэффициентам концентрации установлено, что в водах в большей мере накапливаются $\operatorname{Br}(0,03), \mathrm{I}(0,03)$, $\mathrm{Se}(0,02), \mathrm{Te}(0,02), \operatorname{Re}(0,01)$ и $\mathrm{U}(0,01)$ (рис. 4, б). Это коррелируется с рассчитанными коэффициентами водной миграции (рис. 4, в): очень сильной интенсивностью обладают: I $(355,4), \mathrm{Se}(53,4), \mathrm{Br}(45,9), \mathrm{Te}$ $(30,2), \operatorname{Re}(28,5)$ и $U(12,6)$, сильной: B $(6,5), \operatorname{Sr}(5,1)$, Мо $(2,9)$, средней: $\mathrm{Li}(0,60), \mathrm{Zn}(0,60), \mathrm{Ba}(0,49), \mathrm{Sb}$ $(0,41), \mathrm{Hg}(0,41), \mathrm{Pd}(0,33)$, As $(0,17), \mathrm{P}(0,16), \mathrm{Cu}(0,14)$ и слабой (инертной): $\mathrm{Au}(0,092), \mathrm{Cd}(0,092), \mathrm{Sc}(0,087)$, $\mathrm{Rb}(0,086), \mathrm{Cs}(0,086), \mathrm{W}(0,084), \mathrm{Co}(0,069), \mathrm{Cr}(0,060)$, Si $(0,059), \mathrm{Ni}(0,049), \mathrm{Sn}(0,045), \mathrm{V}(0,025)$, TI $(0,025)$,
$\mathrm{Pb}(0,024), \mathrm{Ge}(0,019), \mathrm{Fe}(0,016), \mathrm{Bi}(0,012), \mathrm{Be}(0,007)$, $\mathrm{Ga}(0,005)$, Th $(0,004)$, Al $(0,002)$, Ti $(0,001)$, Hf $(0,001), \mathrm{Y}(0,001), \mathrm{Zr}(0,0009), \mathrm{Nb}(0,0006)$.

Анализ имеющихся данных выявил особенности вертикальной гидрогеохимической зональности и состава фоновых трещинно-жильных вод гранитоидов, изученных в скважине на ул. Молодежная (№ 10 на рис. 1 , б). Как показали результаты изучения быстроизменяющихся параметров, мощность зоны активной циркуляции подземных вод составляет около 20 м, глубже превалирует затрудненный водообмен с восстановительными условиями геохимической обстановки (Eh от $-81,2$ до $-28,0 \mathrm{mB} ; \mathrm{O}_{2 \text { раств. }}$ от 1,83 до 4,14 мг/дм ${ }^{3}$. Наблюдается инверсия гидрогеохимического разреза и снижение величины общей минерализации от 385-818 мг/дм ${ }^{3}$ на глубинах 7,5-20 м до 483-594 мг/дм ${ }^{3}$ на глубинах 56-70 м. Это сопровождается снижением концентраций $\mathrm{SO}_{4}, \mathrm{Cl}, \mathrm{NO}_{3}, \mathrm{Ca}, \mathrm{Na}$, $\mathrm{Br}, \mathrm{Li}, \mathrm{B}, \mathrm{Al}, \mathrm{V}, \mathrm{Cr}, \mathrm{As}, \mathrm{Se}, \mathrm{Sr}$, I и закономерным ростом F, Sc, Mn, Ga, Rb, Zr, Вa. Высокие содержания последних связаны с водовмещающими гранитами, поскольку в них присутствуют минералыконцентраторы целого ряда химических элементов: флюорит (F, Sc), биотит (Mn, Rb, Ba, Ga), апатит (Sc), циркон $(\mathrm{Zr})$ и сфен $(\mathrm{Mn}, \mathrm{Zr}, \mathrm{F})$. 
Таблица 1. Химический состав природных вод Новобибеевского проявления радоновых вод

Table 1. Chemical composition of natural waters of the Novobibeevo radon-rich waters occurrence

\begin{tabular}{|c|c|c|c|c|c|c|c|c|c|c|c|c|c|c|}
\hline \multirow[b]{2}{*}{ 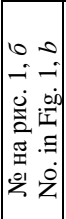 } & \multirow[b]{2}{*}{ 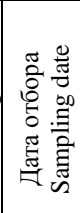 } & \multirow[b]{2}{*}{$\mathrm{pH}$} & Eh & \begin{tabular}{c|l}
$\mathrm{O}_{2}$ & П.ок."
\end{tabular} & $\mathrm{HCO}_{3}{ }^{-}$ & $\mathrm{SO}_{4}{ }^{2-}$ & \begin{tabular}{|l|l|}
$\mathrm{Cl}^{-}$ & $\mathrm{Ca}^{2+}$ \\
\end{tabular} & \begin{tabular}{|l|l|l}
$\mathrm{Mg}^{2+}$ & $\mathrm{Na}^{+}$ & $\mathrm{K}^{+}$ \\
\end{tabular} & $\mathrm{Si}$ & $\mathrm{M}$ & ${ }^{222} \mathrm{Rn}$ & ${ }^{232} \mathrm{Th}$ & ${ }^{238} \mathrm{U}$ & \\
\hline & & & $\vec{\xi}$ & \multicolumn{7}{|c|}{$\begin{array}{l}\mathrm{Mг} / \mathrm{дm}^{3} \\
\mathrm{mg} / \mathrm{dm}^{3}\end{array}$} & 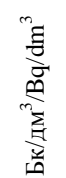 & \multicolumn{2}{|c|}{$\begin{array}{l}\mathrm{Mг} / \mathrm{дm}^{3} \\
\mathrm{mg} / \mathrm{dm}^{3}\end{array}$} & $\begin{array}{c}\text { Химический тип } \\
\text { Chemical type }\end{array}$ \\
\hline
\end{tabular}

Трещинно-жильные воды гранитоидов (группа I)/Fracture-vein waters in granitoids (group I)

\begin{tabular}{l|c|c|c|c|c|c|c|c|c|c|c|c|c|c|c|c|c|c}
2 & 12.11. & 7,5 & $-57,2$ & 4,22 & 1,10 & 378 & 2 & 3 & 78 & 22 & 12 & 1,3 & 7,22 & 498 & 34,7 & $6,80 \cdot 10^{-6}$ & $5,51 \cdot 10^{-4}$ & $\mathrm{HCO}_{3} \mathrm{Mg}-\mathrm{Ca}^{2}$ \\
\hline
\end{tabular}

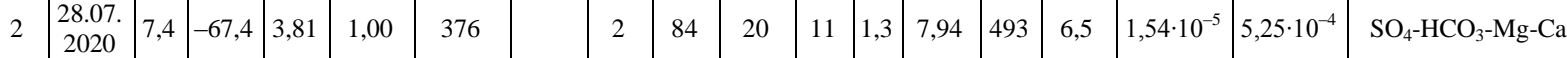

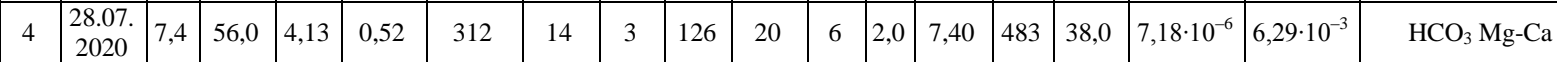

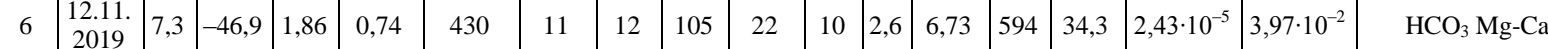

\begin{tabular}{l|c|c|c|c|c|c|c|c|c|c|c|c|c|c|c|c|c|c|c|}
\hline & $\begin{array}{c}28.07 . \\
2020\end{array}$ & 7,3 & $-28,0$ & 4,15 & 0,76 & 405 & 8 & 1 & 96 & 17 & 10 & 2,4 & 13,30 & 539 & 56,5 & $4,04 \cdot 10^{-7}$ & $1,80 \cdot 10^{-3}$ & $\mathrm{HCO}_{3} \mathrm{Mg}_{-} \mathrm{Ca}$
\end{tabular}

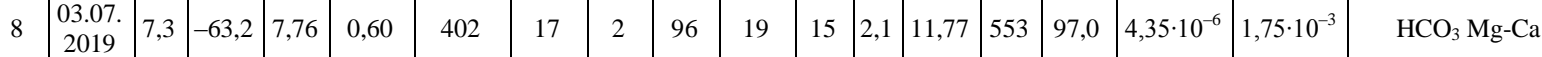

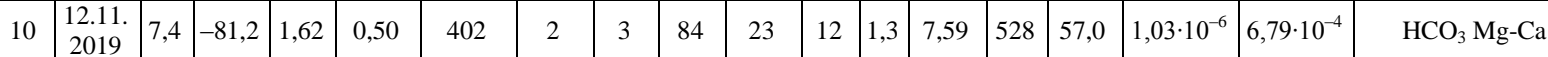

Воды зоны региональной трещиноватости гранитоидов в условиях антропогенного влияния (группа II) Waters of the zone of regional fracturing of granitoids under anthropogenic impact (group II)

\begin{tabular}{l|c|c|c|c|c|c|c|c|c|c|c|c|c|c|c|c|c|c|}
\hline 1 & $\begin{array}{c}12.11 . \\
2019\end{array}$ & 7,5 & 212,7 & 5,78 & 0,13 & 400 & 7 & 10 & 105 & 18 & 6 & 1,6 & 5,77 & 547 & 6,0 & $1,86 \cdot 10^{-7}$ & $1,88 \cdot 10^{-3}$ & $\mathrm{HCO}_{3} \mathrm{Mg}-\mathrm{Ca}$ \\
\hline
\end{tabular}

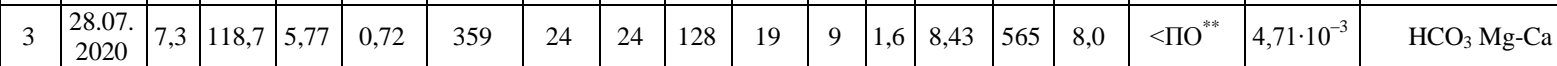

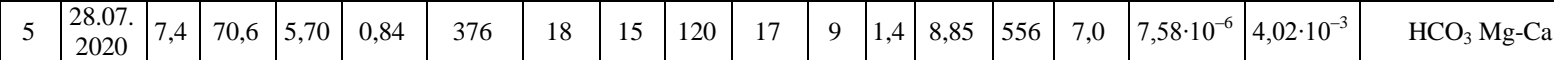

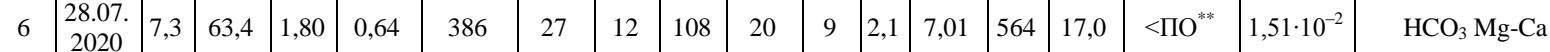

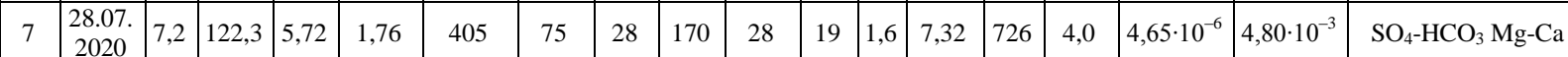

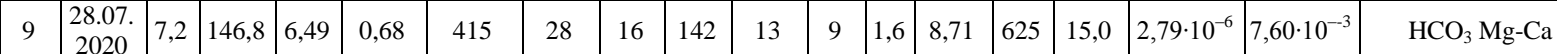

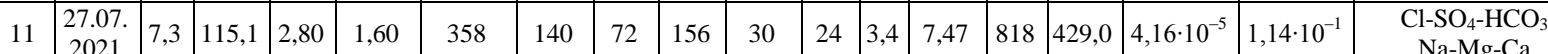

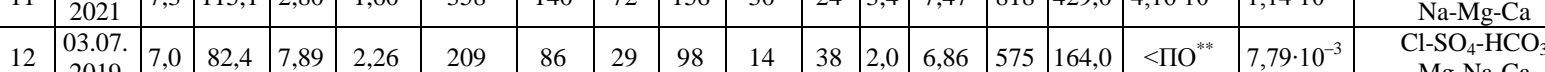

$\mathrm{Mg}-\mathrm{Na}-\mathrm{Ca}$

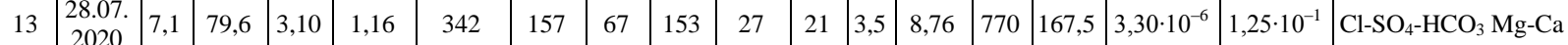

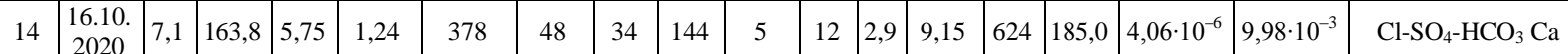

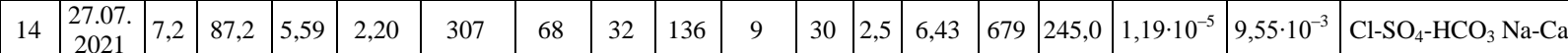

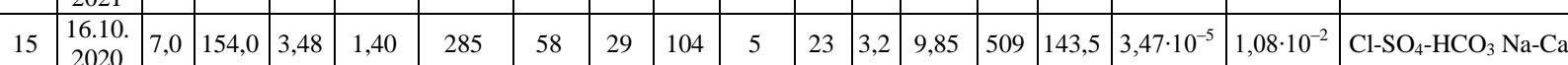

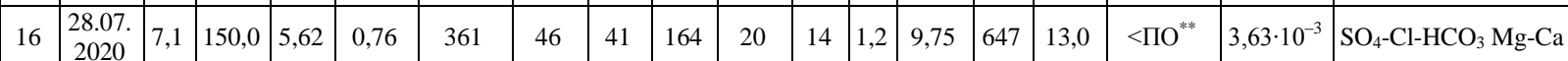

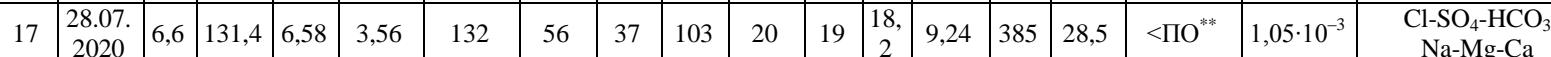

Поверхностные воды в условиях техногенной нарушенности (групnа III)/Surface waters under the conditions of technogenic disturbance (group III)

\begin{tabular}{|c|c|c|c|c|c|c|c|c|c|c|c|c|c|c|c|c|c|c|}
\hline 18 & $\begin{array}{l}03.07 . \\
2019\end{array}$ & 8,0 & 111,0 & 7,91 & 2,24 & 248 & 28 & 3 & 65 & 16 & 20 & 3,0 & 6,49 & 434 & 15,0 & $<\Pi \mathrm{O}^{* *}$ & $1,02 \cdot 10^{-2}$ & $\begin{array}{l}\mathrm{SO}_{4}-\mathrm{HCO}_{3} \\
\mathrm{Na}-\mathrm{Mg}-\mathrm{Ca}\end{array}$ \\
\hline 19 & $\begin{array}{l}03.07 . \\
2019 \\
\end{array}$ & 8,6 & 121,7 & $\begin{array}{c}14,3 \\
9\end{array}$ & 3,00 & 232 & 48 & 3 & 58 & 22 & 20 & 2,3 & 5,02 & 433 & 6,0 & $1,76 \cdot 10^{-5}$ & $1,02 \cdot 10^{-2}$ & $\begin{array}{l}\mathrm{SO}_{4}-\mathrm{HCO}_{3} \\
\mathrm{Na}-\mathrm{Mg}-\mathrm{Ca}\end{array}$ \\
\hline 20 & \begin{tabular}{|l|}
03.07. \\
2019 \\
\end{tabular} & 7,9 & 139,7 & 7,88 & 1,70 & 256 & 40 & 3 & 62 & 25 & 20 & 2,9 & 5,72 & 461 & 39,0 & $2,90 \cdot 10^{-5}$ & $1,08 \cdot 10^{-2}$ & $\begin{array}{l}\mathrm{SO}_{4}-\mathrm{HCO}_{3} \\
\mathrm{Na}-\mathrm{Mg}-\mathrm{Ca} \\
\end{array}$ \\
\hline 21 & $\begin{array}{l}28.07 . \\
2020 \\
\end{array}$ & 8,1 & 145,6 & 7,44 & 1,44 & 268 & 43 & 3 & 72 & 20 & 13 & 4,5 & 9,60 & 423 & 2,0 & $3,10 \cdot 10^{-5}$ & $1,16 \cdot 10^{-2}$ & $\begin{array}{l}\mathrm{SO}_{4}-\mathrm{HCO}_{3} \\
\mathrm{Na}-\mathrm{Mg}-\mathrm{Ca}\end{array}$ \\
\hline 22 & \begin{tabular}{|c|}
03.07. \\
2019 \\
\end{tabular} & 7,8 & 107,8 & 6,49 & 1,80 & 224 & 20 & 3 & 55 & 15 & 20 & 3,3 & 7,00 & 385 & 25,0 & $2,60 \cdot 10^{-6}$ & $1,07 \cdot 10^{-2}$ & $\begin{array}{l}\mathrm{SO}_{4}-\mathrm{HCO}_{3} \\
\mathrm{Na}-\mathrm{Mg}-\mathrm{Ca} \\
\end{array}$ \\
\hline \multicolumn{19}{|c|}{ Поверхностные воды реки Оям (групnа IV)/Surface waters of the Oyash river (group IV) } \\
\hline 23 & \begin{tabular}{|l}
28.07. \\
2020 \\
\end{tabular} & 8,5 & 150,0 & 8,70 & 3,88 & 322 & 8 & 3 & 60 & 1 & 12 & 0,9 & 1,24 & 407 & 12,0 & $1,75 \cdot 10^{-5}$ & $2,27 \cdot 10^{-3}$ & $\mathrm{HCO}_{3}-\mathrm{Na}-\mathrm{Ca}$ \\
\hline 23 & \begin{tabular}{|l|}
27.07. \\
2021 \\
\end{tabular} & 8,5 & 120,1 & 7,45 & 4,50 & 278 & 11 & 4 & 72 & 15 & 16 & 1,0 & 2,87 & 420 & 0,0 & $5,85 \cdot 10^{-6}$ & $2,36 \cdot 10^{-3}$ & $\mathrm{HCO}_{3} \mathrm{Na}-\mathrm{Mg}-\mathrm{Ca}$ \\
\hline 24 & $\begin{array}{l}03.07 \\
2019\end{array}$ & 8,4 & 148,4 & 9,53 & 4,30 & 341 & 13 & 3 & 63 & 25 & 20 & 0,5 & 1,22 & 466 & 1,0 & $6,92 \cdot 10^{-7}$ & $2,77 \cdot 10^{-3}$ & $\mathrm{HCO}_{3} \mathrm{Na}-\mathrm{Mg}-\mathrm{Ca}$ \\
\hline
\end{tabular}

Примечание: * - перманганатная окисляемость; ** - меньше предела обнаружения; *** - название химического типа дано по классификачии С.А. Щукарева (в формулу добавлены макрокомпоненты с содержанием >10 \%-экв).

Note: * - permanganate oxidizability; ** - less than detection limit; *** - water chemical types named using the S.A. Schukarev classification (taking into consideration macrocomponents with content more than $10 \%$-eq). 

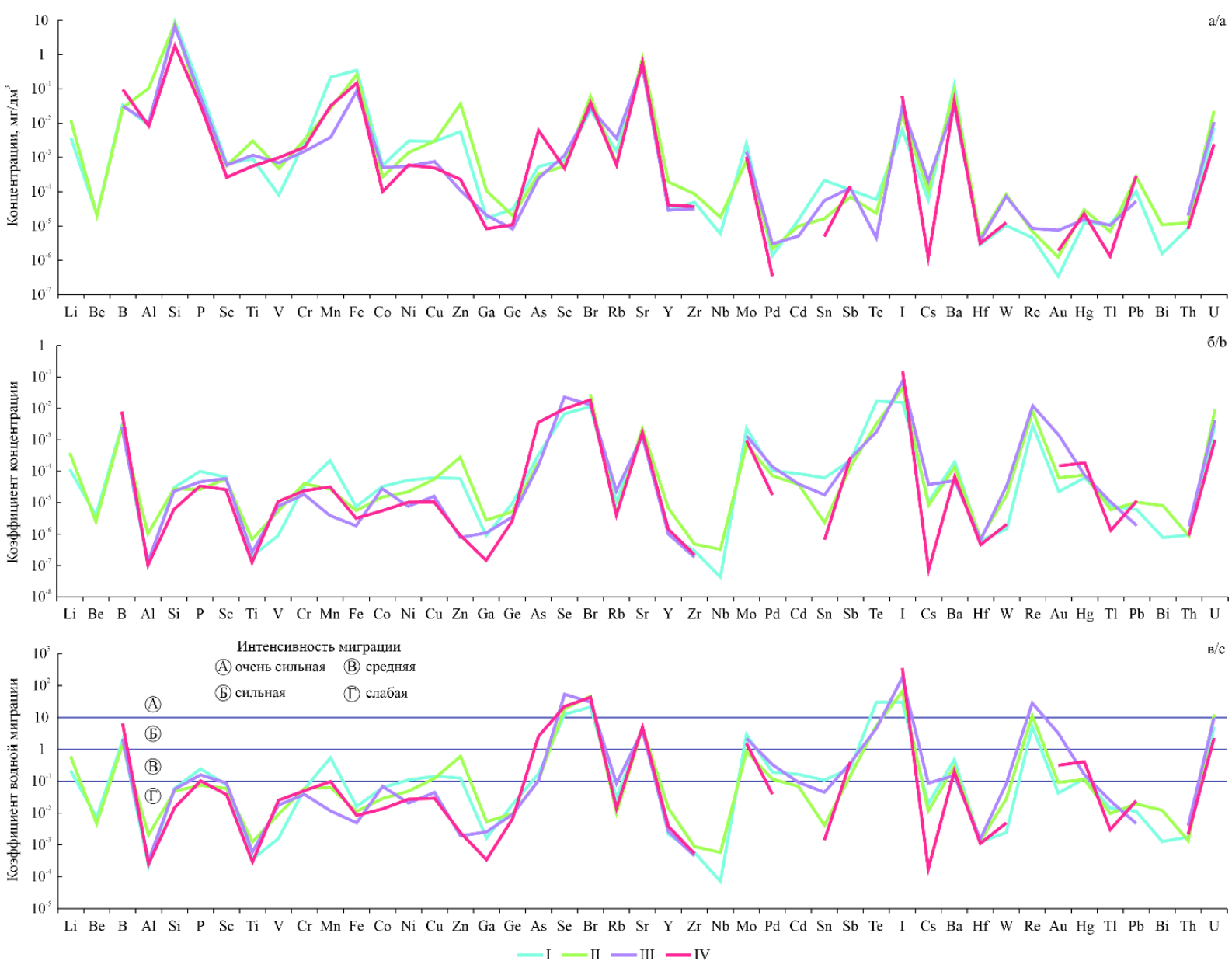

Pис. 4. Спектр распределения микрокомпонентов Новобибеевского проявления (а), распределение коэффициентов концентращий (б), ряды миграции микрокомпонентов в природных водах (в). I - трещцинно-жильные воды гранитоидов; II - воды зоны региональной трещиноватости гранитоидов в условиях антропогенного влияния; III -поверхностные воды в условиях техногенной нарушенности; IV - поверхностные воды реки Ояи

Fig. 4. Spectrum of trace elements distribution of Novobibeevo occurrence (a), distribution of concentration factors $(b)$, microelements migration series in natural waters (c). I-fracture-vein waters in granitoids; II - waters of the zone of regional fracturing of granitoids under anthropogenic impact; III - surface waters under the conditions of technogenic disturbance; IV - surface waters of the Oyash river

\section{Изотопия О, Н и Сріс природных вод}

Состав стабильных изотопов вод - $\delta \mathrm{D}$ и $\delta^{18} \mathrm{O}-$ выступает прямым методом изучения их истории и на текущий момент стал неотъемлемой частью любых гидрогеологических исследований, поскольку позволяет выявить закономерности многих процессов, протекающих в закрытых или слишком масштабных для прямого наблюдения системах [42]. Установление источников влаги [38], генезиса вод [42, 43], процессов их переноса [44], смешения [45], испарения [46], изотопного обмена с окружающими породами и газами [45] - лишь краткий перечень задач, решаемых на основании данных по изотопному составу Н и О вод. Дополнительную информацию о взаимодействии вод с окружением и, как следствие, об истории воды дает изотопный состав углерода в водорастворенной углекислоте - dissolved inorganic carbon (DIC). Значения $\delta^{13} \mathrm{C}_{\text {DIC }}$ определяются широким спектром факторов влияния: источники DIC [47], фракционирование углерода $\mathrm{CO}_{2}$ при переходе из газовой фазы в раствор, влияние процессов дегазации вод [48], изменение изотопного состава DIC при изотопном обмене с окружением, в ходе бактериального преобразования $[47,49]$ и многих других.

Изотопная характеристика отобранных проб приведена в табл. 2 и на рис. 5. Для всех изученных вод характерна слабокислая и слабощелочная среда $(\mathrm{pH}$ изменяется в диапазоне от 6,6 до 8,6), величина общей минерализации варьирует в диапазоне от 385 до 818 мг/л. Превалирующими анионами в большинстве вод выступают $\mathrm{HCO}_{3}{ }^{-}$и $\mathrm{SO}_{4}{ }^{2-}$, содержание которых колеблется от 132 до 430 и от 2 до 157 мг/дм ${ }^{3}$, соответственно, при мольном соотношении $\mathrm{SO}_{4}{ }^{2-} / \mathrm{HCO}_{3}{ }^{-}$ от 0,002 до 0,24. Углекислый газ и карбонат-ион в водах присутствуют либо в следовых количествах, либо ниже порога определения. Концентрация DIC в водах, рассчитанная как сумма диссоциатов угольной кислоты $\left(\mathrm{CO}_{2}+\mathrm{HCO}_{3}{ }^{-}+\mathrm{CO}_{3}{ }^{2-}\right)$, изменяется от 3,4 до 8,7 ммоль/дм ${ }^{3}$. Воды характеризуются диапазоном значений $\delta \mathrm{D}$ и $\delta^{18} \mathrm{O}$ от $-139,4$ до $-112,5 \%$ и от $-18,9$ до $-14,4 \%$, соответственно, при $\delta^{13} \mathrm{C}$ от $-14,0$ до $7,0 \%$. 

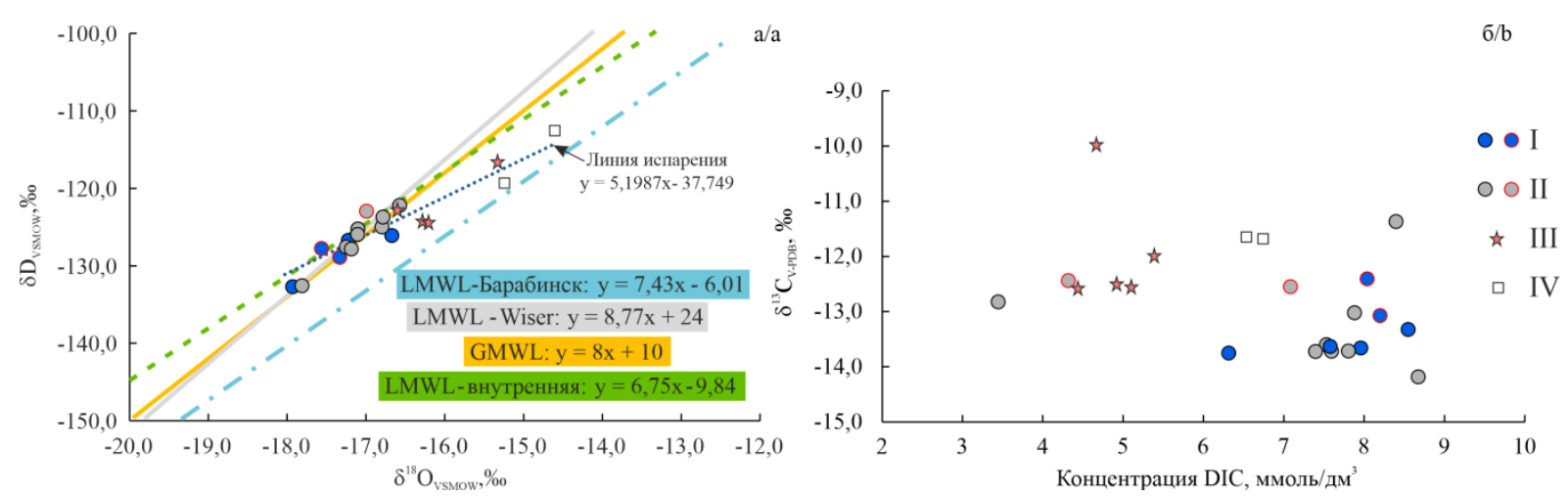

Pис. 5. Изотопный состав кислорода и водорода изученных вод относительно GWML [50] и локальных линий метеорных вод [51] (а); зависимость изотопного состава углерода от кониентрации DIC в водах (б). Условные обозначения - на рис. 1

Fig. 5. Isotope composition of oxygen and hydrogen in the studied waters with respect to GWML [50] and local lines of meteoric waters [51] (a); isotope composition of carbon depending on DIC concentration in waters (b). For designations, see Fig. 1

Значения $\delta \mathrm{D}$ и $\delta^{18} \mathrm{O}$ в изученных водах представлены относительно GMWL [50], LMWL для г. Новосибирска, основанной на данных за 1969-1990 гг. из международной базы данных Wiser [51], а также LMWL, построенной на собственных данных для метеорных осадков, изученных в 2020-2021 гг. Основной массив полученных точек (без учета поверхностных, активно испаряющихся вод) хорошо ложится на все указанные линии метеорных вод, что говорит о метеорном происхождении изученных вод. Ряд точек, отвечающих изотопному составу кислорода и водорода речных и карьерных вод, в определенной степени отклоняется от всех вышеперечисленных линий в сторону утяжеления изотопного состава водорода и кислорода, что является следствием испарения вод с поверхностей этих объектов [42, 43]. Комплекс соответствующих точек может быть охарактеризован общей локальной линией испарения: $\delta \mathrm{D}=5,2 \times \delta^{18} \mathrm{O}-37,7$.

В работах [27, 28] авторы также проводили сравнение полученного изотопного состава $\mathrm{O}$ и $\mathrm{H}$ вод с линиями метеорных вод и в качестве LWML использовали локальные линии для г. Новосибирска за $1969-1990$ гг. $\left(\delta \mathrm{D}=8,77 \times \delta^{18} \mathrm{O}+24,10\right)[51]$ и для г. Барабинска за $1996-2000$ гг. $\left(\delta \mathrm{D}=7,43 \times \delta^{18} \mathrm{O}-6,01\right)$ [51], находящегося в центральной части Новосибирской области. Для выявления причин различия локальных линий и коррекции известных данных в конце 2019 г. было принято решение сделать собственную оценку положения линии метеорных вод, первые результаты которой (для атмосферных осадков в Академгородке г. Новосибирска за 2020 г.) приводятся в настоящей работе: $\delta \mathrm{D}=6,75 \times \delta^{18} \mathrm{O}-9,84$. Работа в этом направлении продолжается, и линия дополняется новыми данными за 2021 г. Из рис. 5, $a$ видно, что полученная локальная линия метеорных вод вполне удовлетворительно описывает данные изотопного состава исследованных объектов, занимая промежуточное положение между известными локальными линиями метеорных вод.

Из представленных на рис. 5, $a$ данных видно, что поверхностные воды отличаются закономерно более тяжелым изотопным составом кислорода и водорода (значения $\delta$ D варьируют от -124 до $-113 \%$ при $\delta^{18} \mathrm{O}$ от $-16,6$ до $-14,6 \%$ ), что обусловлено летним периодом отбора проб, поскольку для подземных вод характерен изотопный состав, усредненный по всему сезону, то есть включающий изотопно-легкие воды холодного периода года [42]. Для подземных вод наблюдается больший дефицит тяжелых изотопов кислорода-18 и дейтерия (значения $\delta \mathrm{D}$ варьируют от -133 до $-122 \%$ при $\delta^{18} \mathrm{O}$ от $-17,9$ до $-16,4 \%$ ). При этом для ряда проб характерна очень малая вариация значений $\delta \mathrm{D}$ и $\delta^{18} \mathrm{O}$ во времени, что хорошо прослеживается для объектов, опробованных в 2019 и 2020 гг.: пары проб № 1 и $6 ; 3$ и $5 ; 2$ и 11; 8 и 17 в табл. 2. В наибольшей степени изменения коснулись проб подземных вод №№ 6-1 и 6-2, отобранных из скважины наименьшей глубины - 7,5 м. По-видимому, в данном случае влияние свежих инфильтрационных вод было проявлено в наибольшей мере.

Поверхностные воды, собранные из р. Ояш в 2019 и 2020 гг., ожидаемо имеют более широкие вариации изотопного состава кислорода и водорода: различие значений $\delta \mathrm{D}$ и $\delta^{18} \mathrm{O}$ составляют, соответственно, 6,0 и $0,6 \%$. Карьерные воды, за исключением озера у его обводненной стенки (проба № 20 в табл. 2: $\delta \mathrm{D}=-117 \%, \delta^{18} \mathrm{O}=-15,3 \%$ ), имеют узкое распределение изотопного состава кислорода и водорода: значения $\delta \mathrm{D}$ варьируют от -124 до $-122 \%$ при $\delta^{18} \mathrm{O}$ от 16,2 до $-16,6 \%$. По значениям $\delta \mathrm{D}$ и $\delta^{18} \mathrm{O}$ карьерные воды занимают промежуточное положение между подземными и речными водами (рис. $5, a$ ). Это позволяет предположить участие в их питании двух источников: атмосферных осадков и подземных вод водоносного горизонта, близкого по изотопному составу к скважинам на ул. Набережная и Лесная (пробы 8, 9, 17 и табл. 2). Эту гипотезу также подтверждают концентрации радона в указанных водах.

Данные о содержании DIC в исследованных водах и его изотопном составе представлены в табл. 2 и на рис. 5, б. Потенциальными источниками DIC в природных водах могут служить атмосферный и почвенный $\mathrm{CO}_{2}$, карбонатные осадочные породы, гидролиз алюмосиликатов, а также органическая (биогенная) 
углекислота $[47,27,52]$, которые впоследствии могут изменяться в ходе изотопного обмена, протекающего в процессах выветривания пород и обмена вод газами с окружением [52, 53].

Полученные значения $\delta^{13} \mathrm{C}_{\text {DIC }}$ варьируют в диапазоне от $-14,2$ до $-10,0 \%$ при содержании DIC от 3,4 до 8,7 ммоль/дм ${ }^{3}$. Концентрация DIC в исследованных водах превышает его естественную концентрацию в дождевой воде $\left(10^{-2}\right.$ ммоль/дм ${ }^{3}$ [47]) на 2-3 порядка, что позволяет сделать вывод о незначительности вклада растворенного атмосферного углекислого газа в формировании DIC. Основным источником водорастворенной углекислоты в данном случае следует рассматривать почвенную углекислоту смешанного состава: диффузионную (близкую по изотопному со- ставу углерода к атмосферному $\mathrm{CO}_{2}$ ) и биогенную (с выраженным отрицательным изотопным составом углерода). Для более точного учета источников углекислоты в водах, а также ее участия в процессах карбонат-силикатного выветривания требуется более детальное исследование окружающей водоемы флоры, массивов горных пород и прочих факторов, что не является на текущий момент главной целью исследования. Тем не менее из рис. 5, 6 видно, что с увеличением содержания DIC в водах в целом вклад изотопно-легкой углекислоты становится большим (значения $\delta^{13} \mathrm{C}_{\text {DIC }}$ становятся более отрицательными). Наибольшее обогащение изотопно-легким углеродом характерно для подземных вод.

Таблица 2. Изотопный состав вод и DIC на территории с. Новобибиево

Table 2. Isotope composition of water and DIC at the territory of Novobibeevo settlement

\begin{tabular}{|c|c|c|c|c|c|c|c|}
\hline \multirow{2}{*}{$\begin{array}{l}\text { № пп/ } \\
\text { no. pp }\end{array}$} & \multirow{2}{*}{$\begin{array}{l}\text { № на рис. } \\
1, \text { б/No. in } \\
\text { Fig. } 1, b\end{array}$} & \multirow{2}{*}{$\begin{array}{c}\text { Дата отбора } \\
\text { Sampling date }\end{array}$} & $\delta \mathrm{D}_{\text {VSMOW }}$ & $\delta^{18} \mathrm{O}_{\mathrm{VSMOW}}$ & $\delta^{13} \mathrm{C}_{\mathrm{VPDB}}$ & \multirow{2}{*}{$\begin{array}{c}\sum \mathrm{DIC}, \\
\text { ммоль/дм } \\
\mathrm{mmol} / \mathrm{l}\end{array}$} & \multirow[t]{2}{*}{$\mathrm{HCO}_{3} / \mathrm{SO}_{4}$} \\
\hline & & & \multicolumn{3}{|c|}{$\%$} & & \\
\hline \multicolumn{8}{|c|}{ Трещинно-жильные воды гранитоидов (группа I)/Fracture-vein waters in granitoids (group I) } \\
\hline 1 & 8 & 03.07 .2019 & -129 & $-17,3$ & $-12,4$ & 8,0 & 43,49 \\
\hline 2 & 6 & 12.11 .2019 & -133 & $-17,9$ & $-13,3$ & 8,6 & 72,47 \\
\hline 3 & 2 & 12.11 .2019 & -127 & $-17,2$ & $-13,6$ & 7,6 & 342,07 \\
\hline 4 & 10 & 12.11 .2019 & -126 & $-16,7$ & $-13,7$ & 8,0 & 414,05 \\
\hline 5 & 2 & 28.07 .2020 & -126 & $-17,0$ & $-13,6$ & 7,5 & - \\
\hline 6 & 8 & 28.07 .2020 & -128 & $-17,6$ & $-13,1$ & 8,2 & 95,29 \\
\hline 7 & 4 & 28.07 .2020 & -127 & $-17,5$ & $-13,8$ & 6,3 & 40,78 \\
\hline \multicolumn{8}{|c|}{$\begin{array}{c}\text { Воды зоны региональной трещиноватости гранитоидов в условиях антропогенного влияния (группа II) } \\
\text { Waters of the zone of regional fracturing of granitoids under anthropogenic impact (group II) }\end{array}$} \\
\hline 8 & 12 & 03.07 .2019 & -124 & $-16,4$ & $-12,4$ & 4,3 & 4,57 \\
\hline 9 & 1 & 12.11 .2019 & -124 & $-16,8$ & $-13,0$ & 7,9 & 114,89 \\
\hline 10 & 5 & 28.07 .2020 & -128 & $-17,2$ & $-13,6$ & 7,5 & 39,99 \\
\hline 11 & 6 & 28.07 .2020 & -133 & $-17,8$ & $-13,7$ & 7,8 & 26,61 \\
\hline 12 & 7 & 28.07 .2020 & -125 & $-16,8$ & $-11,4$ & 8,4 & 10,16 \\
\hline 13 & 17 & 28.07 .2020 & -122 & $-16,6$ & $-12,8$ & 3,4 & 4,44 \\
\hline 14 & 16 & 28.07 .2020 & -128 & $-17,2$ & $-13,7$ & 7,6 & 14,77 \\
\hline 15 & 3 & 28.07 .2020 & -125 & $-17,1$ & $-13,7$ & 7,4 & 28,16 \\
\hline 16 & 9 & 28.07 .2020 & -126 & $-17,1$ & $-14,2$ & 8,7 & 28,20 \\
\hline 17 & 13 & 28.07 .2020 & -123 & $-17,0$ & $-12,6$ & 7,1 & 4,10 \\
\hline \multicolumn{8}{|c|}{$\begin{array}{l}\text { Поверхностные воды в условиях техногенной нарушенности (группа III) } \\
\text { Surface waters under the conditions of technogenic disturbance (group III) }\end{array}$} \\
\hline 18 & 22 & 03.07 .2019 & -123 & $-16,6$ & $-12,6$ & 4,4 & 20,77 \\
\hline 19 & 18 & 03.07 .2019 & -124 & $-16,3$ & $-12,5$ & 4,9 & 16,67 \\
\hline 20 & 19 & 03.07 .2019 & $\begin{array}{l}-117 \\
\end{array}$ & $-15,3$ & $-10,0$ & 4,7 & 9,10 \\
\hline 21 & 20 & 03.07 .2019 & -124 & $-16,2$ & $-12,6$ & 5,1 & 12,02 \\
\hline 22 & 21 & 28.07 .2020 & -122 & $-16,5$ & $-12,0$ & 5,4 & 11,73 \\
\hline \multicolumn{8}{|c|}{ Поверхностные воды реки Оями (групnа IV)/Surface waters of the Oyash river (group IV) } \\
\hline 23 & 24 & 03.07.2019 & -119 & $-15,2$ & $-11,7$ & 6,7 & 50,15 \\
\hline 24 & 23 & 28.07 .2020 & -113 & $-14,6$ & $-11,7$ & 6,5 & 76,43 \\
\hline
\end{tabular}

\section{Выводы}

Таким образом, можно сделать следующие выводы:

1. В гидрогеологическом разрезе Новобибеевского проявления радоновые воды приурочены к безнапорному водоносному горизонту верхнепалеозойских гранитов Обского массива. Интрузивные породы разбиты сетью трещин, образующих единую обводненную зону трещинных вод, водообильность которой крайне мала. Вскрытая мощность обводненных гранитоидов достигает 120 м. Высокоомные значения УЭС (1000-2000 Ом·м) указывают на низкую трещиноватость и обводненность пород. Низкие значения УЭС (20-100 Ом·м) свидетельствуют о наличии обводненной зоны трещиноватости в гранитоидах.

2. Анализ имеющихся данных позволил впервые выделить четыре геохимические совокупности вод: трещинно-жильные воды гранитоидов (группа I), воды зоны региональной трещиноватости гранитоидов в условиях антропогенного влияния (группа II), поверхностные воды в условиях техногенной нарушенности (группа III) и поверхностные воды реки Ояш (группа IV). Радоновые воды характеризуются преимущественно $\mathrm{HCO}_{3}$ $\mathrm{Mg}-\mathrm{Ca}$ и $\mathrm{Cl}-\mathrm{SO}_{4}-\mathrm{HCO}_{3} \mathrm{Na}-\mathrm{Ca}$ составом. Величина общей минерализации составляет 509-818 мг/дм³ а содержания кремния 6,43-13,30 мг/дм ${ }^{3}$. Геохи- 
мические параметры среды изменяются от восстановительной до окислительной обстановки с величинами Eh от $-63,1$ до $+163,8 \mathrm{mB}, \mathrm{pH}$ от 7,0 до 7,3 и $\mathrm{O}_{2 \text { раств. }}$ От 2,80 до 7,89 мг/дм ${ }^{3}$. Концентрации радионуклидов варьируют $\left(\right.$ мг/дм $\left.{ }^{3}\right):{ }^{238} U$ от $1,75 \cdot 10^{-3}$ до $1,25 \cdot 10^{-1}$ и ${ }^{232} \mathrm{Th}$ от $4,04 \cdot 10^{-7}$ до $4,14 \cdot 10^{-5} \cdot{ }^{232} \mathrm{Th} /{ }^{238} \mathrm{U}$ отношение в радоновых водах изменяется в интервале от $2,63 \cdot 10^{-5}$ до $3,20 \cdot 10^{-3}$ при среднем $1,14 \cdot 10^{-3}$. Активность радона в водах варьирует от 70 до 429 Бк/дм³

3. С ростом общей минерализации в растворе концентрируются $\mathrm{Li}, \mathrm{Cr}, \mathrm{Zn}, \mathrm{Br}, \mathrm{Sr}$ и U, снижаются содержания B, V, As, Nb, Mo, Au. Коэффициенты концентрации свидетельствуют о накоплении в водах $\mathrm{Br}, \mathrm{I}, \mathrm{Se}, \mathrm{Te}, \mathrm{Re}$ и U. Очень сильной интенсивностью водной миграции обладают: I, Se, Br, Te, Re и U, сильной: B, Sr, Mo, средней: Li, Zn, Ba, $\mathrm{Sb}, \mathrm{Hg}, \mathrm{Pd}, \mathrm{As}, \mathrm{P}, \mathrm{Cu}$ и слабой (инертной) $\mathrm{Au}, \mathrm{Cd}$, Sc, Rb, Cs, W, Co, Cr, Si, Ni, Sn, V, TI, Pb Ge, Fe, $\mathrm{Bi}, \mathrm{Be}, \mathrm{Ga}, \mathrm{Th}, \mathrm{Al}, \mathrm{Ti}, \mathrm{Hf}, \mathrm{Y}, \mathrm{Zr}, \mathrm{Nb}$.

4. По результатам изучения быстроизменяющихся параметров мощность зоны активной циркуляции подземных вод составляет около 20 м, глубже превалирует затрудненный водообмен с восстановительными условиями геохимической обстанов-

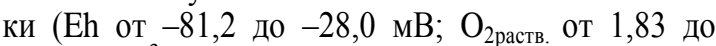
4,14 мг/дм $\left.{ }^{3}\right)$. Наблюдается инверсия гидрогеохимического разреза и снижение величины общей минерализации от $385-18$ мг/дм ${ }^{3}$ на глубинах 7,5-20 м до 483-594 мг/дм ${ }^{3}$ на глубинах 56-70 м.

\section{СПИСОК ЛИТЕРАТУРЬ}

1. Вернадский В.И. Труды по радиогеологии. - М.: Наука, 1997. $-319 \mathrm{c}$

2. Distribution characteristics and influencing factors of uranium isotopes in saline lake waters in the northeast of Qaidam Basin C. Zhao, P. Zhang, X. Li, Y. Ning, L. Tan, R.L. Edwards, X. Yao, H. Cheng // Minerals. - 2020. - V. 10 (1). - P. 74.

3. Fractionation of rare earth elements (REEs) and actinides (U and Th) originating from acid thermal water during artificial and natural neutralization processes of surface waters / Y. Ogawa D. Ishiyama, N. Shikazono, K. Iwane, T. Hoshino, M. Kajiwara, N. Tsuchiya, B. Saini-Eiduka, S.A. Wood // Geochimica et Cosmochimica Acta. - 2019. - V. 249. - P. 247-262.

4. Faraj T., Ragab A., Alfy M.E. Geochemical and hydrogeologica factors influencing high levels of radium contamination in groundwater in arid regions // Environmental Research. - 2020. V. 184. - 109303

5. Geochemical controls on dispersion of $U$ and Th in Quaternary deposits, stream water, and aquatic plants in an area with a granite pluton / C. Yu, T. Berger, H. Drake, Z. Song, P. Peltola, M.E.Åström // Science of the Total Environment - 2019- - V. 663 - P. 16-28

6. High resolution multi-annual riverine fluxes of organic carbon, nutrient and trace element from the largest European Arctic river, Severnaya Dvina / A.V. Chupakov, O.S. Pokrovsky, O.Y. Moreva, L.S. Shirokova, N.V. Neverova, A.A. Chupakova, E.I. Kotova, T.Y. Vorobyeva // Chemical Geology. - 2020. - V. 538 (13). 119491.

7. Physico-chemical conditions controlling the radionuclides mobilisation in various granitic environments / A.M. El-Mezayen, E.M. Ibrahim, M.G. El-Feky, S.M. Omar, A.M. El-Shabasy, S.A. Taalab // International Journal of Environmental Analytical Chemistry. - 2020. - P. 1-17.

8. Radium isotopes to trace uranium redox anomalies in anoxic Groundwater / L. Krall, L. Auqué-Sanz, J. Garcia-Orellana, G. Trezzi, E.-L. Tullborg, J. Suksi, D. Porcelli, P. Andersson // Chemical Geology. - 2019. - V. 531. - 119296.
Это сопровождается снижением концентраций $\mathrm{SO}_{4}, \mathrm{Cl}, \mathrm{NO}_{3}, \mathrm{Ca}, \mathrm{Na}, \mathrm{Br}, \mathrm{Li}, \mathrm{B}, \mathrm{Al}, \mathrm{V}, \mathrm{Cr}, \mathrm{As}, \mathrm{Se}, \mathrm{Sr}$, I и закономерным ростом $\mathrm{F}, \mathrm{Sc}, \mathrm{Mn}, \mathrm{Ga}, \mathrm{Rb}, \mathrm{Zr}, \mathrm{Ba}$. 5. Изотопный состав $(\delta \mathrm{D}$ от $-139,4$ до $-112,5 \%$ и $\delta^{18} \mathrm{O}$ от $-18,9$ до $-14,4 \%$ ) и расположение точек на диаграмме $\delta \mathrm{D}=\mathrm{f}\left(\delta^{18} \mathrm{O}\right)$ указывает на метеорное происхождение всех изученных вод. Ряд точек, отвечающих изотопному составу кислорода и водорода речных и карьерных вод в определенной степени отклоняется от GMWL, LMWL для г. Новосибирска, LMWL, построенной на собственных данных для метеорных осадков, собранных за 2020 г. в сторону утяжеления изотопного состава водорода и кислорода, что является следствием испарения вод с поверхностей указанных объектов. Полученные значения $\delta^{13} \mathrm{C}_{\text {DIC }}$ варьируют в диапазоне от $-14,2$ до $-10,0$ \%о при содержании DIC от 3,4 до 8,7 ммоль/дм ${ }^{3}$. Концентрация DIC в водах превышает его естественную концентрацию в дождевой воде, что указывает на незначительный вклад растворенного атмосферного углекислого газа в формировании DIC. Основным источником водорастворенной углекислоты является почвенная углекислота смешанного состава.

Исследование выполнено при финансовой поддержке проектов Министерства науки и высшего образования РФ №№ FWZZ-2022-0014 u FSWW-0022-2020, РФФИ $u$ Правительства Новосибирской области в рамках грантов № 20-45-543004 и 20-45-543005.

9. The aqueous chemistry of polonium (Po) in environmental and anthropogenic processes / R. Ram, J. Vaughan, B. Etschmann, J. Brugger // Journal of Hazardous Materials. - 2019. - V. 380. 120725

10. Артамонова С.Ю. Содержание урана и радия-226 в подземных рассолах сибирской платформы // Интерэкспо Гео-Сибирь. 2019. - T. 2. - № 3. - C. 225-231.

11. Distribution, contamination and source identification of heavy metals in bed sediments from the lower reaches of the Xiangjiang River in Hunan province, China / X. Fang, B. Peng, X. Wang, Z. Song, D. Zhou, Q. Wang, Z. Zhilian Qin, C. Changyin Tan // Science of the Total Environment. - 2019. - V. 689. - P. 557-570.

12. Some naturally occurring radionuclides (NORM) in a river affected by acid mining drainages / G. Manjón, J. Mantero, I. Vioque, J. Galván, I. Díaz-Francés, R. García-Tenorio // Chemosphere. - 2019. - V. 223. - P. 536-543.

13. Assessment of metal and metalloid contamination in the waters and stream sediments around the abandoned uranium mine area from Mortórios, central Portugal / A.M.R. Neiva, P.C.S. Carvalho, I.M.H.R. Antunes, M.T.D. Albuquerque, A.C.S. Santos, P.P. Cunha, S.B.A. Henriques // Journal of Geochemical Exploration. - 2019. - V. 202. - P. 35-48.

14. Characteristics and assessment of toxic metal contamination in surface water and sediments near a uranium mining area / L. Yi, B. Gao, H. Liu, Y. Zhang, C. Du, Y. Li // International Journal of Environmental Research and Public Health. - 2020. - V. 17. P. 548.

15. Thorium and uranium distribution in a passive system for mine water treatment / M.I. Prudêncio, T. Valente, R. Marques, M.A.S. Braga, J. Pamplona // E3S Web of Conferences. - 2019. V. 98. -09023.

16. Wang Z., Qin H., X Liu. Health risk assessment of heavy metals in the soil-water-rice system around the Xiazhuang uranium mine, China // Environmental Science and Pollution Research. - 2019. V. 26. - P. 5904-5912.

17. ${ }^{238} \mathrm{U}$ and ${ }^{232} \mathrm{Th}$ isotopes in groundwater of Jordan: geological influence, water chemistry, and health impact / A.H. Alomari, 
M.A. Saleh, S. Hashim, A. Alsayaheen, I. Abdeldin, A. Abukashabeh // Radiation Physics and Chemistry. - 2020. V. 170. -108660

18. Sources of $U$ and $T h$ in groundwater of the paleobeach aquifer at Cox's Bazar, Southeast Bangladesh / A.A. Seddique, Y. Kon, R. Anma, H. Masuda, P. Bhattacharya, Y. Yokoo, S.B. Basak, K. Shinoda // Groundwater for Sustainable Development. - 2020. V. 10. - 100332 .

19. Посохов Е.В., Толстихин Н.И. Минеральные воды (лечебные, промышленные, энергетические). - М.: Недра, 1977. - 240 с.

20. Гусев В.К., Вериго Е.К. Радоновые воды Колывань-Томской складчатой зоны, их использование и охрана // Изменение природных условий под влиянием деятельности человека. Новосибирск: Наука, Сибирское отделение, 1984. - С. 99-107.

21. Вериго Е.К., Быкова В.В., Гусев В.К. Заельцовское месторождение радоновых вод (Новосибирское Приобье) // Новые данные по геологии и полезным ископаемым Западной Сибири. 1979. - № 14. - С. 47-51.

22. Гидрогеология и гидрогеохимия месторождения радоновых вод «Каменское» (г. Новосибирск) / Д.А. Новиков, А.Ф. Сухорукова, Т.В. Корнеева, Р. Каменова-Тотцева, А.А. Максимова А.С. Деркачев, Ф.Ф. Дульцев, А.В. Черных // Известия Томского политехнического университета. Инжиниринг георесурсов. -2021 . - Т. 332. - № 4. - С. 192-208.

23. Новиков Д.А., Сухорукова А.Ф., Корнеева Т.В. Гидрогеология и гидрогеохимия Заельцовско-Мочищенского проявления радоновых вод (юг Западной Сибири) // Геодинамика и тектонофизика. - 2018. - Т. 9. - № 4. - С. 1255-1274.

24. Novikov D.A., T Korneeva.V. Microelements in radon waters of the Zaelsovsky field (the southern part of West Siberia) // Journal of Physics: Conference Series. - 2019. - V. 1172. - № 012096.

25. Novikov D.A., Dultsev F.F., Chernykh A.V. Role of water-rock interactions in the formation of the composition of radon waters of the Zaeltsovsky field (the southern part of West Siberia) // Journal of Physics: Conference Series. - 2020. - V. 1451 (1). - № 012007.

26. Изотопно-геохимические особенности проявления слаборадоновых вод «Инские источники» (юг Западной Сибири) / Д.А. Новиков, Ю.Г. Копылова, Л.Г. Вакуленко, А.Ф. Сухорукова, А.Н. Пыряев, А.А. Максимова, Ф.Ф. Дульцев, А.В. Черных // Известия Томского политехнического университета. Инжиниринг георесурсов. - 2021. - Т. 332. - № 3. - С. 135-145.

27. Первые данные по изотопному составу пластовых вод разрабатываемых нефтяных месторождений Новосибирской области / Д.А. Новиков, А.Н. Пыряев, А.В. Черных, Ф.Ф. Дульцев, C.В. Рыжкова // Известия Томского политехнического университета. Инжиниринг георесурсов. - 2021. - Т. 332. - № 2. C. $59-72$.

28. Hydrogeological conditions and hydrogeochemistry of radon waters in the Zaeltsovsky-Mochishche zone of Novosibirsk, Russia / D.A. Novikov, F.F. Dultsev, R. Kamenova-Totzeva, T.V. Korneeva // Environmental Earth Sciences. - 2021. - V. 80. № 6. - Article 216

29. Monitoring of radionuclides in the natural waters of Novosibirsk, Russia / D.A. Novikov, F.F. Dultsev, A.F. Sukhorukova, A.A. Maksimova, A.V. Chernykh, A.S. Derkachyov // Groundwater for Sustainable Development. - 2021. - V. 15. - 100674.

30. A new radon prediction approach for an assessment of radiologica potential in drinking water / L.M.O. Martins, A.J.S.C. Pereira A. Sousa Oliveira, L.F. Sanches Fernandes, F.A.L. Pacheco // Science of The Total Environment. - 2020. - V. 712. - 136427.

31. Ullah F., Muhammad S., Ali W. Radon concentration and potential risks assessment through hot springs water consumption in the Gilgit and Chitral, Northern Pakistan // Chemosphere. - 2022. V. 287. - 132323

32. Duggal V., Sharma S., Mehra R. Risk assessment of radon in drinking water in Khetri Copper Belt of Rajasthan, India // Chemosphere. - 2020. - V. 239. - 124782

33. Radium measurements in bottled natural mineral-, spring- and medicinal waters from Poland / I. Chmielewska, S. Chałupnik, M. Wysocka, A. Smoliński // Water Resources and Industry. - 2020. V. 24. -100133

34. The first large-scale mapping of radon concentration in soil gas and water in Romania / B. Burghele, A. Țenter, A. Cucos, T. Dicu, M. Moldovan, B. Papp, K. Szacsvai, T. Neda, L. Suciu,
A. Lupulescu, C. Malos, S. Florică, C. Baciu, C. Sainzae // Science of The Total Environment. - 2019. - V. 669. - P. 887-892.

35. Epstein S., Mayeda T. Variation of O 18 content of waters from natural sources // Geochimica et Cosmochimica Acta. - 1953. V. 4 (5). - P. 213-224

36. Nelson S.T. A simple, practical methodology for routine VSMOW/SLAP normalization of water samples analysed by continuous flow methods // Rapid Communications in Mass Spectrometry. - 2000. - V. 4. - P. 1044-1046.

37. Evans M.J., Derry L.A., France-Lanord C. Degassing of metamorphic carbon dioxide from the Nepal Himalaya // Geochemistry, Geophysics, Geosystems. - 2008. - V. 9 (4). P. 1-18.

38. Seasonal deuterium excess variations of precipitation at Summit, Greenland, and their climatological significance / B.G. Kopec, X. Feng, E.S. Posmentier, et al. // Journal of Geophysical Research: Atmospheres. - 2019. - V. 124. - P. 72-91.

39. Григорьев Н.А. Распределение химических элементов в верхней части континентальной коры. - Екатеринбург: УрО РАН, 2009. -383 c

40. Объяснительная записка к Геологической карте СССР. Серия Кузбасская. Масштаб 1:200000. Лист N-44-VI / под ред. Д.В. Михайловский, В.А. Мартынов. - М.: Союзгеолфонд, 1979. - 90 c

41. Перельман А.И. Геохимия ландшафта. изд. 2-е. - М.: Высшая школа, 1975. - 342 c.

42. Ферронский В.И., Поляков В.А. Изотопия гидросферы. - М.: Научный мир, 2009. - 632 с.

43. Hoefs J. Stable isotope geochemistry. 8th ed. - Berlin: Springer International Publ. AG, part of Springer Nature, 2018. - 460 p.

44. Васильчук Ю.К., Чижова Ю.Н. Высотный градиент распределения $\delta 180$ и $\delta \mathrm{D}$ в атмосферных осадках и в снежном покрове высокогорных районов // Криосфера Земли. - 2010. - T. XIV № 1. - C. 13-21.

45. Specifying recharge zones and mechanisms of the transitional geothermal field through hydrogen and oxygen isotope analyses with consideration of water-rock interaction / R.M. Shoedarto, Y. Tada, K. Kashiwaya, K. Koike, I. Iskandar // Geothermics. 2020. - V. 86. - 101797.

46. Hydrochemical and isotopic characterization of groundwater in the Ghis-Nekor plain (northern Morocco) / D. Chafouq, A. El Mandour, M. Elgettafi, M. Himi, I. Chouikri, A. Casas // Journal of African Earth Sciences. - 2018. - V. 139. - P. 1-13.

47. Das A., Krishnaswami S., Bhattacharya S.K. Carbon isotope ratio of dissolved inorganic carbon (DIC) in rivers draining the Deccan Traps, India: sources of DIC and their magnitudes // Earth and Planetary Science Letters. - 2005. - V. 236. - P. 419-429.

48. Quantifying carbon isotope disequilibrium during in-cave evolution of drip water along discreet flow paths / P.J. Mickler, P. Carlson, J.L. Banner, D.O. Breecker, L. Stern, A. Guilfoyle // Geochimica et Cosmochimica Acta. - 2019. - V. 244. - P. 182-196.

49. Новые данные по изотопному составу $\left(\delta^{13} \mathrm{C}, \delta \mathrm{D}, \delta{ }^{18} \mathrm{O},{ }^{87} \mathrm{Rb} /{ }^{86} \mathrm{Sr}\right.$ и ${ }^{87} \mathrm{Sr} /{ }^{86} \mathrm{Sr}$ ) рассолов сибирской платформы / Д.А. Новиков, А.Н. Пыряев, А.В. Черных, Ф.Ф. Дульцев, А.В. Ильин, Е.О. Чертовских // Известия Томского политехнического университета. Инжиниринг георесурсов. - 2021. - Т. 332. - № 7. C. $20-33$.

50. Craig H. Isotopic variations in meteoric waters // Science. - 1961. V. 133. - P. 1702-1703.

51. International Atomic Energy Agency. URL: https://www.iaea.org/ resources/nucleus-information-resources (дата обращения 05.12.2021)

52. Первые изотопно-гидрогеохимические данные по природным водам юго-восточного склона кряжа Чекановского (Арктические районы Сибирской платформы) / Д.А. Новиков, А.А. Максимова, А.Н. Пыряев, П.А. Ян / Известия Томского политехнического университета. Инжиниринг георесурсов. 2020. - T. 331. - № 11. -C. 157-167.

53. Karim A., Veizer J. Weathering processes in the Indus River Basin implications from carbon, sulfur, oxygen and strontium isotopes // Chemical Geology. - 2000. - V. 170. - P. 153-177.

Поступила 08.12.2021 2. 


\section{Информация об авторах}

Новиков Д.А., кандидат геолого-минералогических наук, заведующий лабораторией гидрогеологии осадочных бассейнов Сибири Института нефтегазовой геологии и геофизики им. А.А. Трофимука СО РАН; доцент кафедры геологии месторождений нефти и газа и кафедры общей и региональной геологии Новосибирского национального исследовательского государственного университета.

Дульцев Ф.Ф., научный сотрудник лаборатории гидрогеологии осадочных бассейнов Сибири Института нефтегазовой геологии и геофизики им. А.А. Трофимука СО РАН.

Максимова A.A., инженер лаборатории гидрогеологии осадочных бассейнов Сибири Института нефтегазовой геологии и геофизики им. А.А. Трофимука СО РАН; ассистент кафедры минералогии и геохимии Новосибирского национального исследовательского университета.

Пыряев $\boldsymbol{A . H . , ~ к а н д и д а т ~ х и м и ч е с к и х ~ н а у к , ~ н а у ч н ы и ̆ ~ с о т р у д н и к ~ л а б о р а т о р и и ~ и з о т о п н о - а н а л и т и ч е с к о и ̆ ~ г е о х и м и и ~}$ Института геологии и минералогии им. В.С. Соболева СО РАН; старший преподаватель кафедры химической и биологической физики Новосибирского национального исследовательского государственного университета.

Фаге A.H., кандидат технических наук, научный сотрудник лаборатории электромагнитных полей Института нефтегазовой геологии и геофизики им. А.А. Трофимука СО РАН.

Хващевская $\boldsymbol{A . A . , ~ к а н д и д а т ~ г е о л о г о - м и н е р а л о г и ч е с к и х ~ н а у к , ~ д о ц е н т , ~ з а в е д у ю щ а я ~ п р о б л е м н о и ̆ ~ н а у ч н о - ~}$ исследовательской лабораторией гидрогеохимии Инженерной школы природных ресурсов Национального исследовательского Томского политехнического университета, доцент отделения геологии Инженерной школы природных ресурсов Национального исследовательского Томского политехнического университета.

Деркачев A.C., студент, Новосибирский национальный исследовательский государственный университет.

Черных $\boldsymbol{A}$.В., научный сотрудник лаборатории гидрогеологии осадочных бассейнов Сибири Института нефтегазовой геологии и геофизики им. А.А. Трофимука СО РАН. 
UDC 551.464.3 (1-924.71)

\section{INITIAL RESULTS OF THE INTEGRATED ISOTOPE-HYDROGEOCHEMICAL STUDIES OF THE NOVOBIBEEVO OCCURRENCE OF RADON-RICH WATERS}

\author{
Dmitry A. Novikov ${ }^{1,2}$, \\ NovikovDA@ipgg.sbras.ru
}

Fedor F. Dultsev1, DultsevFF@ipgg.sbras.ru

Anastasia A. Maksimova2,1, rock.nastaya64@gmail.com

\section{Aleksandr N. Pyryaev 3,2 ,} pyrayev@igm.nsc.ru

\author{
Aleksey N. Fage 1 , \\ FaguetAN@ipgg.sbras.ru
}

\author{
Albina A. Khvashchevskaya ${ }^{4}$, \\ unpc_voda@mail.ru
}

Anton S. Derkachev²,
a.derkachev@g.nsu.ru

Anatoliy V. Chernykh ${ }^{1}$, ChernykhAV@ipgg.sbras.ru

1 Trofimuk Institute of Petroleum Geology and Geophysics SB RAS,

3 , Koptyug avenue, Novosibirsk, 630090, Russia.

2 Novosibirsk State University,

1, Pirogov street, Novosibirsk, 630090, Russia.

3 Institute of Geology and Mineralogy SB RAS,

3, Koptyug avenue, Novosibirsk, 630090, Russia

4 National Research Tomsk Polytechnic University,

30, Lenin avenue, Tomsk, 634050, Russia.

The relevance of the investigation is in obtaining the first isotope-geochemical data on natural waters and embedding rocks at the Novobibeevo occurrence of radon-rich waters.

Goal: to study the features of the chemical composition of natural waters and water-bearing rocks and to obtain the first data on the activity of ${ }^{222} \mathrm{Rn}$ and on the isotope composition: $\delta D, \delta^{18} \mathrm{O}, \delta^{13} \mathrm{C}$.

Methods. Laboratory investigation of chemical composition by means of tritrimetry, ion chromatography, mass spectrometry with inductively coupled plasma was carried out in Basic Research Laboratory of Hydrogeochemistry at the School of Earth Sciences and Engineering of the Tomsk Polytechnic University. Determination of a set of characteristics $-\delta D, \delta^{18} \mathrm{O}, \delta^{13} \mathrm{C}_{\mathrm{DIC}}$ waters and dissolved inorganic carbon (DIC) - was carried out in the Shared Equipment Center at the Institute of Geology and Mineralogy SB RAS using an Isotope Ratio Mass Spectrometer Finnigan ${ }^{T M}$ MAT 253, equipped with the attachments for sample preparation H/Device (to determined $\delta D$ ) and GasBench II (to determine $\delta^{18} \mathrm{O}$ and $\delta^{13} \mathrm{CDIC}$ ). The concentration of ${ }^{222} \mathrm{Rn}$ in water samples was measured with the Alfarad Plyus complex at the Laboratory of Hydrogeology of the Sedimentary Basins of Siberia of the IPGG SB RAS. Geophysical studies were carried out using the electrical exploration equipment Skala-48 with 48 electrodes and a $5 \mathrm{~m}$ step between them, according to the Schlumberger electrical exploration scheme. Data separation into uniform geochemical entities was performed using the coefficients $\mathrm{Ca} / \mathrm{Na}, \mathrm{Ca} / \mathrm{Mg}, \mathrm{Ca} / \mathrm{Si}, \mathrm{Mg} / \mathrm{Si}$, $\mathrm{Na} / \mathrm{Si}$. To reveal the degrees of chemical element concentration in natural waters, we calculated the concentrating coefficients $K k_{i}=\frac{m_{x}}{n_{x}}$, and water migration coefficients (according to A.I. Perelman) $K x_{1}=\frac{m_{x} \cdot 100}{a \cdot n_{x}}$.

Results. Integrated isotope-geochemical studies of radon-rich waters of the Novobibeevo occurrence have been carried out. Radon-rich waters (222Rn activity up to $429 \mathrm{~Bq} / \mathrm{dm}^{3}$ ) are mainly characterized by $\mathrm{HCO}_{3} \mathrm{Mg}$-Ca composition with total mineralization (TDS) from 385 to $818 \mathrm{mg} / \mathrm{dm}^{3}$ and silicon content from 5,77 to $13,30 \mathrm{mg} / \mathrm{dm}^{3}$. The geochemical parameters of the environment vary from the reductive to oxidative setting with Eh from -81,2 to +212,7 mV; pH from 6,6 to 7,5, and $\mathrm{O}_{2 d i s s o l v e d}$ from 1,62 to 7,89 $\mathrm{mg} / \mathrm{dm}^{3}$. Goundwaters were divided into two geochemical groups: 1) fracture-vein waters of granitoids with the ratios $\mathrm{Ca} / \mathrm{Si} 11,49 ; \mathrm{Mg} / \mathrm{Si} 248 ; \mathrm{Na} / \mathrm{Si} 1,25 ; \mathrm{Si} / \mathrm{Na} 0,87 ; \mathrm{Ca} / \mathrm{Na}$ 10,02; $\mathrm{Ca} / \mathrm{Mg} 4,76 ; \mathrm{rNa} / \mathrm{rCl} 8,79$, and $\mathrm{SO}_{4} / \mathrm{Cl} 4,35$, and 2) waters of the zone of regional fracturing of granitoids under anthropogenic influence, with the ratios $\mathrm{Ca} / \mathrm{Si}$ 16,3; $\mathrm{Mg} / \mathrm{Si}$ 2,21; $\mathrm{Na} / \mathrm{Si}$ 2,21; Si/Na 0,62; $\mathrm{Ca} / \mathrm{Na}$ 9,84; $\mathrm{Ca} / \mathrm{Mg} 9,95 ; \mathrm{rNa} / \mathrm{rCl} \mathrm{0,89}$ and SO$/ \mathrm{Cl} 1,78$. The composition of surface waters under the conditions of technogenic disturbance is $\mathrm{SO}_{4}-\mathrm{HCO}_{3} \mathrm{Na}-\mathrm{Mg}$-Ca with TDS from 385 to $461 \mathrm{mg} / \mathrm{dm}^{3}$ and silicon content from 5,02 to $9,60 \mathrm{mg} / \mathrm{dm}^{3}$. The geochemical parameters of the environment correspond to the oxidative setting with Eh from

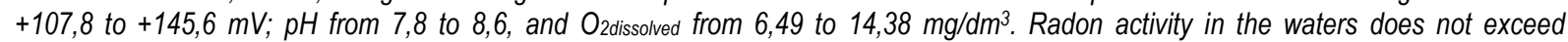
$39 \mathrm{~Bq} / \mathrm{dm}^{3}$. The surface waters of the Oyash river are characterized mainly by the $\mathrm{HCO}_{3} \mathrm{Na}-\mathrm{Mg}$-Ca composition with TDS from 407 to $466 \mathrm{mg} / \mathrm{dm}^{3}$ and silicon content from 1,22 to $2,87 \mathrm{mg} / \mathrm{dm}^{3}$. The geochemical parameters of the environment correspond to the oxidative

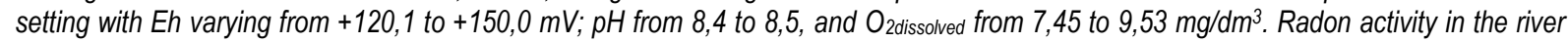
water varies from 1 to $12 \mathrm{~Bq} / \mathrm{dm}^{3}$. With an increase in total mineralization, the elements that are concentrated in radon-rich waters are Li, $\mathrm{Cr}, \mathrm{Zn}, \mathrm{Br}, \mathrm{Sr}$ and $\mathrm{U}$, which is accompanied by a decrease in the concentrations of $\mathrm{B}, \mathrm{V}, \mathrm{As}, \mathrm{Nb}, \mathrm{Mo}$ and $\mathrm{Au}$. In the spectrum of element distribution, the highest content (mg/dm $\mathrm{dm}^{3}$ ) was consistently determined for Si up to 8,85, Mn up to 0,22, Fe up to 0,34, Sr up to 0,77, and $B a$ up to 0,13 , because water-bearing rocks are represented by biotite granites, porphyry-like and olivine dolerites. The elements accumulated in waters to a higher extent are $\mathrm{Br}, \mathrm{I}, \mathrm{Se}, \mathrm{Te}, \mathrm{Re}$ and $\mathrm{U}$. The stable isotope composition ( $\delta \mathrm{D}$ values varying from $-139,4$ to $-112,5 \%$ and $\delta^{18} \mathrm{O}$ values varying from $-18,9$ to $-14,4 \%$ ) of waters and position of experimental points on the ( $\delta D$ vs $\left.\delta^{18} \mathrm{O}\right)$-plot indicating the meteoric origin of all the studied waters. The obtained $\delta^{13} \mathrm{C}_{\text {DIC }}$ values vary from $-14,2$ to $-10,0 \%$, with DIC content from 3,4 to $8,7 \mathrm{mmol} / \mathrm{L}$. The main source of DIC is soil carbon dioxide of the mixed composition. 


\section{Key words:}

Radon waters, stable isotopes, radon, genesis of waters, granites, new radon water occurrence Novobibeevskoe, the Novosibirsk Region, West Siberia.

The research was financially supported by projects no. FWZZ-2022-0014 and FSWW-0022-2020 of the Ministry of Science and Education of the Russian Federation, the Russian Foundation for Basic Research and Government of the Novosibirsk region within the framework of grants no. 20-45-543004 and 20-45-5430.

\section{REFERENCES}

1. Vernadsky V.I. Trudy po radiogeologii [Works on radiogeology]. Moscow, Nauka Publ., 1997. 319 p.

2. Zhao C., Zhang P., Li X., Ning Y., Tan L., Edwards R.L., Yao X., Cheng $\mathrm{H}$. Distribution characteristics and influencing factors of uranium isotopes in saline lake waters in the northeast of Qaidam Basin. Minerals, 2020, vol. 10 (1), pp. 74.

3. Ogawa Y., Ishiyama D., Shikazono N., Iwane K., Hoshino T., Kajiwara M., Tsuchiya N., Saini-Eiduka B., Wood S.A. Fractionation of rare earth elements (REEs) and actinides (U and Th) originating from acid thermal water during artificial and natural neutralization processes of surface waters. Geochimica et Cosmochimica Acta, 2019, vol. 249, pp. 247-262

4. Faraj T., Ragab A., Alfy M.E. Geochemical and hydrogeological factors influencing high levels of radium contamination in groundwater in arid regions. Environmental Research, 2020 vol. 184, 109303

5. Yu C., Berger T., Drake H., Song Z., Peltola P., Åström M.E. Geochemical controls on dispersion of $U$ and $T h$ in Quaternary deposits, stream water, and aquatic plants in an area with a granite pluton. Science of the Total Environment, 2019, vol. 663, pp. 16-28.

6. Chupakov A.V., Pokrovsky O.S., Moreva O.Y., Shirokova L.S. Neverova N.V., Chupakova A.A., Kotova E.I., Vorobyeva T.Y. High resolution multi-annual riverine fluxes of organic carbon, nutrient and trace element from the largest European Arctic river, Severnaya Dvina. Chemical Geology, 2020, vol. 538 (13), 119491.

7. El-Mezayen A.M., Ibrahim E.M., El-Feky M.G., Omar S.M., El-Shabasy A.M., Taalab S.A. Physico-chemical conditions controlling the radionuclides mobilisation in various granitic environments. International Journal of Environmental Analytical Chemistry, 2020, pp. 1-17.

8. Krall L., Auqué-Sanz L., Garcia-Orellana J., Trezzi G., Tullborg E.-L., Suksi J., Porcelli D., Andersson P. Radium isotopes to trace uranium redox anomalies in anoxic Groundwater. Chemical Geology, 2019, vol. 531, 119296

9. Ram R., Vaughan J., Etschmann B., Brugger J. The aqueous chemistry of polonium (Po) in environmental and anthropogenic processes. Journal of Hazardous Materials, 2019, vol. 380 120725 .

10. Artamonova S.Yu. Isotopes of uran and radium in underground Brines of Siberian plate. Interexpo Geo-Siberia, 2019, vol. 2, no. 3 , pp. 225-231. In Rus.

11. Fang X., Peng B., Wang X., Song Z., Zhou D., Wang Q., Zhilian Qin Z., Changyin Tan C. Distribution, contamination and source identification of heavy metals in bed sediments from the lower reaches of the Xiangjiang River in Hunan province, China. Science of the Total Environment, 2019, vol. 689, pp. 557-570.

12. Manjón G., Mantero J., Vioque I., Galván J., Díaz-Francés I., García-Tenorio R. Some naturally occurring radionuclides (NORM) in a river affected by acid mining drainages. Chemosphere, 2019, vol. 223, pp. 536-543.

13. Neiva A.M.R., Carvalho P.C.S., Antunes I.M.H.R., Albuquerque M.T.D., Santos A.C.S., Cunha P.P., Henriques S.B.A. Assessment of metal and metalloid contamination in the waters and stream sediments around the abandoned uranium mine area from Mortórios, central Portugal. Journal of Geochemical Exploration, 2019, vol. 202, pp. $35-48$.

14. Yi L., Gao B., Liu H., Zhang Y., Du C., Li Y. Characteristics and assessment of toxic metal contamination in surface water and sediments near a uranium mining area. International Journal of Environmental Research and Public Health, 2020, vol. 17, pp. 548.

15. Prudêncio M.I., Valente T., Marques R., Braga M.A.S., Pamplona J Thorium and Uranium distribution in a passive system for mine water treatment. E3S Web of Conferences, 2019, vol. 98, 09023
16. Wang Z., Qin H., Liu X. Health risk assessment of heavy metals in the soil-water-rice system around the Xiazhuang uranium mine, China. Environmental Science and Pollution Research, 2019, vol. 26, pp. 5904-5912.

17. Alomari A.H., Saleh M.A., Hashim S., Alsayaheen A., Abdeldin I., Abukashabeh A. ${ }^{238} \mathrm{U}$ and ${ }^{232} \mathrm{Th}$ isotopes in groundwater of Jordan: geological influence, water chemistry, and health impact. Radiation Physics and Chemistry, 2020, vol. 170, 108660.

18. Seddique A.A., Kon Y., Anma R., Masuda H., Bhattacharya P., Yokoo Y., Basak S.B., Shinoda K. Sources of U and Th in groundwater of the paleobeach aquifer at Cox's Bazar, Southeast Bangladesh. Groundwater for Sustainable Development, 2020, vol. 10,100332 .

19. Posokhov E.V., Tolstikhin N.I. Mineralnye vody (lechebnye, promyshlennye, energeticheskie) [Mineral waters (healing, industrial, energy)]. Moscow, Nedra Publ., 1977. 240 p.

20. Gusev V.K., Verigo E.K. Radonovye vody Kolyvan-Tomskoy skladchatoy zony, ikh ispolzovanie [Radon waters of the KolyvanTomsk fold zone, their use and protection]. Izmenenie prirodnykh uslovy pod vliyaniem deyatelnosti cheloveka [Change in natural conditions under the influence of human activity]. Novosibirsk, Nauka, Siberian branch, 1984. p. 99-107.

21. Verigo E.K., Bykova V.V., Gusev V.K. Zaeltsovskoe mestorozdenie radonovykh vod (Novosibirskoe Priobye) [Zaeltsovsky deposit of radon waters (Novosibirsk Priobye)]. New data on geology and minerals of Western Siberia, 1979, Iss. 14, pp. 47-51.

22. Novikov D.A., Sukhorukova A.F., Korneeva T.V., KamenovaTotseva R., Maksimova A.A., Derkachev A.S., Dultsev F.F., Chernykh A.V. Hydrogeology and hydrogeochemistry of the «Kamenskoe» field of radon-rich waters (Novosibirsk). Bulletin of the Tomsk Polytechnic University. Geo Assets Engineering, 2021, vol. 332, no. 4, pp. 192-208. In Rus.

23. Novikov D.A., Sukhorukova A.F., Korneeva T.V. Hydrogeology and hydrogeochemistry of the Zaeltsovsko-Mochishchensky zone of radon waters in the southern West Siberia. Geodynamics \& Tectonophysics, 2018, vol. 9, no. 4, pp. 1255-1274. In Rus.

24. Novikov D.A., Korneeva T.V. Microelements in radon waters of the Zaelsovsky field (the southern part of West Siberia). Journal of Physics: Conference Series, 2019, vol. 1172, 012096.

25. Novikov D.A., Dultsev F.F., Chernykh A.V. Role of water-rock interactions in the formation of the composition of radon waters of the Zaeltsovsky field (the southern part of West Siberia). Journal of Physics: Conference Series, 2020, vol. 1451 (1), no. 012007.

26. Novikov D.A., Kopylova Yu.G., Vakulenko L.G., Sukhorukova A.F., Pyryaev A.N., Maksimova A.A., Dultsev F.F., Chernykh A.V. Isotope geochemical features of occurrence of low-radon waters «Inskie springs» (south-western Siberia). Bulletin of the Tomsk Polytechnic University. Geo Assets Engineering, 2021, vol. 332, no. 3, pp. 135-145. In Rus.

27. Novikov D.A., Pyryaev A.N., Chernykh A.V., Dultsev F.F., Ryzhkova S.V. The first data on the isotopic composition of stratal waters of the developed oil fields in Novosibirsk region. Bulletin of the Tomsk Polytechnic University. Geo Assets Engineering, 2021, vol. 332, no. 2, pp. 59-72. In Rus.

28. Novikov D.A., Dultsev F.F., Kamenova-Totzeva R., Korneeva T.V. Hydrogeological conditions and hydrogeochemistry of radon waters in the Zaeltsovsky-Mochishche zone of Novosibirsk, Russia. Environmental Earth Sciences, 2021, vol. 80, no. 6, article 216.

29. Novikov D.A., Dultsev F.F., Sukhorukova A.F., Maksimova A.A., Chernykh A.V., Derkachyov A.S. Monitoring of radionuclides in the natural waters of Novosibirsk, Russia. Groundwater for Sustainable Development, 2021, vol. 15, 100674

30. Martins L.M.O., Pereira A.J.S.C., Sousa Oliveira A., Sanches Fernandes L.F., Pacheco F.A.L. A new radon prediction approach for 
an assessment of radiological potential in drinking water. Science of The Total Environment, 2020, vol. 712, 136427

31. Ullah F., Muhammad S., Ali W. Radon concentration and potential risks assessment through hot springs water consumption in the Gilgit and Chitral, Northern Pakistan. Chemosphere, 2022, vol. 287, 132323

32. Duggal V., Sharma S., Mehra R. Risk assessment of radon in drinking water in Khetri Copper Belt of Rajasthan, India. Chemosphere, 2020, vol. 239, 124782

33. Chmielewska I., Chałupnik S., Wysocka M., Smoliński A. Radium measurements in bottled natural mineral-, spring- and medicinal waters from Poland. Water Resources and Industry, 2020, vol. 24 100133

34. Burghele B., Țenter A., Cucoş A., Dicu T., Moldovan M., Papp B., Szacsvai K., Neda T., Suciu L., Lupulescu A., Maloș C., Florică Ş., Baciu C., Sainzae C. The FIRST large-scale mapping of radon concentration in soil gas and water in Romania. Science of The Total Environment, 2019, vol. 669, pp. 887-892.

35. Epstein S., Mayeda T. Variation of O 18 content of waters from natural sources. Geochimica et Cosmochimica Acta, 1953, vol. 4 (5), pp. 213-224

36. Nelson S.T. A simple, practical methodology for routine VSMOW/SLAP normalization of water samples analysed by continuous flow methods. Rapid Communications in Mass Spectrometry, 2000, vol. 4, pp. 1044-1046.

37. Evans M.J., Derry L.A., France-Lanord C. Degassing of metamorphic carbon dioxide from the Nepal Himalaya. Geochemistry, Geophysics, Geosystems, 2008, vol. 9 (4), pp. 1-18.

38. Kopec B.G., Feng X., Posmentier E.S. Seasonal deuterium excess variations of precipitation at Summit, Greenland, and their climatological significance. Journal of Geophysical Research: Atmospheres, 2019, vol. 124, pp. 72-91.

39. Grigoryev N. A. Raspredelenie khimicheskikh elementov v verkh ney chasti kontinentalnoy kory [Distribution of chemical elements in the upper continental crust]. Yekaterinburg, Ural Branch of RAS Publ., 2009. 383 p.

40. Mikhaylovskiy D.V., Martynov V.A. Obyasnitelnaya zapiska $k$ Geologicheskoy karte SSSR. Seriya Kuzbasskaya. Masshtab 1:200000. List N-44-VI [Explanatory note to the Geological map of the USSR. Kuzbass series. Scale 1:200000. Sheet N-44-VI]. Moscow, Soyuzgeolfond Publ., 1979. 90 p.

41. Perelman A.I. Geokhimiya landshafta [Landscape geochemistry] Moscow, Vysshaya shkola Publ., 1975. 342 p.
42. Ferronsky V.I., Polyakov V.A. Izotopiya gidrosfery [Isotopy of the hydrosphere]. Moscow, Nauchny mir Publ., 2009. 632 p.

43. Hoefs J. Stable isotope geochemistry. $8^{\text {th }}$ ed. Berlin, Springer International Publishing AG, part of Springer Nature, 2018. $460 \mathrm{p}$

44. Vasilchuk Yu.K., Chizhova Yu.N. Altitudinal gradient of $\delta 180$ and $\delta \mathrm{D}$ in precipitation and snow cover in high mountains. Earth's Cryosphere, 2010, vol. XIV, no. 1, pp. 13-21. In Rus.

45. Shoedarto R.M., Tada Y., Kashiwaya K., Koike K., Iskandar I. Specifying recharge zones and mechanisms of the transitional geothermal field through hydrogen and oxygen isotope analyses with consideration of water-rock interaction. Geothermics, 2020, vol. 86, 101797.

46. Chafouq D., El Mandour A., Elgettafi M., Himi M., Chouikri I., Casas A. Hydrochemical and isotopic characterization of groundwater in the Ghis-Nekor plain (northern Morocco). Journal of African Earth Sciences, 2018, vol. 139, pp. 1-13.

47. Das A., Krishnaswami S., Bhattacharya S.K. Carbon isotope ratio of dissolved inorganic carbon (DIC) in rivers draining the Deccan Traps, India: Sources of DIC and their magnitudes. Earth and Planetary Science Letters, 2005, vol. 236, pp. 419-429.

48. Mickler P.J., Carlson P., Banner J.L., Breecker D.O., Stern L., Guilfoyle A. Quantifying carbon isotope disequilibrium during incave evolution of drip water along discreet flow paths. Geochimica et Cosmochimica Acta, 2019, vol. 244, pp. 182-196.

49. Novikov D.A., Pyryaev A.N., Chernykh A.V., Dultsev F.F., Ilyin A.V., Chertovskikh E.O. New data on the isotopic composition $\left(\delta^{13} \mathrm{C}\right.$, $\delta \mathrm{D}, \delta^{18} \mathrm{O},{ }^{87} \mathrm{Rb} /{ }^{86} \mathrm{Sr}$ and ${ }^{87} \mathrm{Sr} /{ }^{86} \mathrm{Sr}$ ) of the Siberian platform brines. Bulletin of the Tomsk Polytechnic University. Geo Assets Engineering, 2021, vol. 332, no. 7, pp. 20-33. In Rus.

50. Craig H. Isotopic variations in meteoric waters. Science, 1961, vol. 133, pp. 1702-1703.

51. International Atomic Energy Agency. Available at: https://www. iaea.org/resources/nucleus-information-resources (accessed 05 December 2021)

52. Novikov D.A., Maksimova A.A., Pyryaev A.N., Yan P.A. First isotope-hydrogeochemical data on the natural waters of the southeast slope of the Chekanovsky ridge (Arctic areas of the Siberian platform). Bulletin of the Tomsk Polytechnic University. Geo Assets Engineering, 2020, vol. 331, no. 11, pp. 157-167. In Rus.

53. Karim A., Veizer J. Weathering processes in the Indus River Basin implications from carbon, sulfur, oxygen and strontium isotopes. Chemical Geology, 2000, 170, pp. 153-177.

Received: 8 December 2021.

\section{Information about the authors}

Dmitry A. Novikov, Cand. Sc., head of the laboratory, Trofimuk Institute of Petroleum Geology and Geophysics of Siberian Branch of Russian Academy of Sciences; associate professor, Novosibirsk State University.

Fedor F. Dultsev, researcher, Trofimuk Institute of Petroleum Geology and Geophysics of Siberian Branch of Russian Academy of Sciences.

Anastasia A. Maksimova, assistant, Novosibirsk State University; engineer, Trofimuk Institute of Petroleum Geology and Geophysics of Siberian Branch of Russian Academy of Sciences.

Aleksandr N. Pyryaev, Cand. Sc., researcher, Institute of Geology and Mineralogy of Siberian Branch of Russian Academy of Sciences; senior lecturer, Novosibirsk State University.

Aleksey N. Fage, Cand. Sc., researcher, Trofimuk Institute of Petroleum Geology and Geophysics of Siberian Branch of Russian Academy of Sciences.

Albina A. Khvashchevskaya, Cand. Sc., head of the scientific laboratory, National Research Tomsk Polytechnic University.

Anton S. Derkachev, student, Novosibirsk State University.

Anatoliy V. Chernykh, researcher, Trofimuk Institute of Petroleum Geology and Geophysics of Siberian Branch of Russian Academy of Sciences. 